Article

\title{
Evaluation of Changes in Glomalin-Related Soil Proteins (GRSP) Content, Microbial Diversity and Physical Properties Depending on the Type of Soil as the Important Biotic Determinants of Soil Quality
}

\author{
Anna Gałązka ${ }^{1, *(D)}$, Jacek Niedźwiecki ${ }^{2}$, Jarosław Grządziel ${ }^{1}$ (D) and Karolina Gawryjołek ${ }^{1}$ \\ 1 Department of Agriculture Microbiology, Institute of Soil Science and Plant Cultivation—State Research \\ Institute, Czartoryskich 8, 24-100 Pulawy, Poland; jgrzadziel@iung.pulawy.pl (J.G.); \\ kgaw@iung.pulawy.pl (K.G.) \\ 2 Department of Soil Science Erosion and Land Conservation, Institute of Soil Science and Plant \\ Cultivation-State Research Institute, Czartoryskich 8, 24-100 Pulawy, Poland; jacekn@iung.pulawy.pl \\ * Correspondence: agalazka@iung.pulawy.pl; Tel.: +48-814-786-950
}

Received: 20 August 2020; Accepted: 26 August 2020; Published: 29 August 2020

\begin{abstract}
The aim of the study was to evaluate the changes in glomalin-related soil proteins (GRSP) content, microbial diversity and soil physical quality depending on the type of soil measures of soil improvement and changes in soil health. The study was based on a 100-year stationary field microplot experiment where the soil profiles were collected with preserving the natural soil horizons. The microplot experiment was carried out on eight different soil types: Brunic Arenosol (Dystric I), Rendzic Leptosol, Fluvic Cambisol, Haplic Cambisol (Eutric), Gleyic Phaeozem, Brunic Arenosol (Dystric II), Haplic Cambisol (Eutric II) and Haplic Cambisol (Dystric). These soils are the most common types of agricultural soils in Poland. Relatively significant correlations with the soil quality, physical parameters and the glomalin-related soil proteins have been found. The study determined the total GRSP (T-GRSP) and easily extractable GRSP (EE-GRSP) levels in soils as well as the soil physical quality index and soil's microbial biodiversity. The GRSP depended on the type of soil and correlated with S-Index and also was responsible for the unique chemical and physical properties of soils. Soils characterized by the highest T-GRSP content belonged to the group of very good and good soil physical quality characterized also by high biological activity, for which there were strong correlations with such parameters as dehydrogenase activity (DHA), microbial biomass content (MBC), microbial nitrogen content (MBN) and total bacteria number (B). The highest T-GRSP content and higher microbial diversity were found in Gleyic Phaeozem, Rendzic Leptosol and Fluvic Cambisol. The T-GRSP and EE-GRSP content were additionally correlated with the number of AMF spores. Very poor and poor soil physical quality according to S-Index characterized Brunic Arenosol (Dystric I) and Haplic Cambisol (Dystric). This research indicates that a specific edaphone of soil microorganisms and GRSP content may be of great importance when assessing a soil's quality and improvements in soil health. The abundance of glomalin-producing fungi significantly affects the quality of the soil. This effect is particularly important for agricultural soils are threatened by ongoing land degradation.
\end{abstract}

Keywords: clay dispersion; soil properties; arbuscular mycorrhizal fungi (AMF); Dexter's soil physical quality index; $\mathrm{S}$ index; microbial activity 


\section{Introduction}

Organic matter $(\mathrm{OM})$ and the products of its biochemical transformation have a favourable effect on a complex of soil properties that determine its fertility and productivity [1,2]. OM plays a major role in the formation of soil structure and exerts a strong impact on water infiltration, root development and resistance to erosion [3]. Organic matter serves as a store of nutrients and determines cation-exchange capacity. The quality of Polish agricultural soils are rated as the poorest in Europe [3,4]. Production potential of an average hectare of Polish soil equal to 0.6 ha of arable land in the EU. That is why it is so important to properly manage soil resources in the context of the proper functioning of ecosystems and the special protection of high-performance soils [3]. This is mainly due to the type of parent material of soils. Over 70\% of Poland's soils were mainly formed from Pleistocene sands, highly blurred and sorted by glacial waters [4]. Also, some soils were formed from boulder clays. In Poland, such soil types as Brunic Arenosol (Dystric I), Rendzic Leptosol, Fluvic Cambisol, Haplic Cambisol (Eutric), Gleyic Phaeozem, Brunic Arenosol (Dystric II), Haplic Cambisol (Eutric II) and Haplic Cambisol (Dystric) constitute about $75 \%$ of the land. These soils are widely used in agriculture for the cultivation of cereals $[3,4]$. The fundamental assumption of sustainable agriculture is to protect the natural environment and ensure biodiversity in agrocenoses. The abundance of soil microorganisms and higher enzymatic activity are sensitive indicators of the soil biological activity and an appropriate complex of properties determining soil fertility. The well-functioning soil is determined by enhanced biological activity and also a healthy soil also providing a more suitable ecosystem for soil biota. Any changes in soil properties may induce changes in the abundance and activity of soil microorganisms in terms of their species composition and function [2,5].

The quality of soils is connected not only with their microbiological properties but also with its physical and chemical properties [2,6]. Water availability and $\mathrm{pH}$ are also important factors affecting the number and activity of microorganisms and ecological relationships between them [7]. In soils with properties favourable for plant production, e.g., texture, soil aggregates, higher OM content and higher $\mathrm{pH}$, intensive development of bacteria is observed [7]. On the other hand, the growth of fungi over bacteria is favoured by drier soil conditions [8]. Soil type is also of great importance for environmental biodiversity. The study of Grządziel et al. [9,10] indicated that differences in bacterial and fungal composition are affected directly by the soil type [5,9-11]. Mycorrhizal fungi also play a large role in maintaining proper biocenosis of the soil environment and, at the same time, soil stability $[12,13]$.

Arbuscular mycorrhizal fungi (AMF) are one of the most important biotic determinants of soil environment quality $[12,13]$. They play a very important role in agrarian ecosystems and, through the production of glomalin related soil proteins, can exert a positive effect on plant growth and health depending on the type of soil [13]. GRSP are glicoproteins that are very characteristic in terms of their structure and physicochemical properties [14]. Glomalin related soil proteins in literature is reportedly a stable and persistent protein produced in copious quantities by mycorrhizal fungi and may be an important pool of organic $\mathrm{N}$ in soil [13,14]. GRSP is only operationally defined by its extraction method as the total glomalin related soil proteins (T-GRSP) and easily extracted glomalin related soil proteins (EE-GRSP) [12]. Gillespie et al. [14] conducted research aimed at evaluation of glomalin structure and their characterization. On the basis of modern research methods such as synchrotron-based X-ray absorption near-edge structure (XANES) spectroscopy and pyrolysis field-ionization mass spectrometry (Py-FIMS) authors revealed that GRSP contains a consortium of proteins along with many impurities [14]. On the basis of employing proteomic techniques, Gillespie et al. [14] found that glomalin related soil proteins itself may be a thioredoxin-containing chaperone. The authors did not find no homologies with proteins or DNA of mycorrhizal origin were detected. In addition on the basis of proteomics techniques the authors have proved that GRSP contains large amounts of soil-related heat-stable proteins and proteins of non-mycorrhizal origin [14]. Therefore, based on the Gillespie et al. research [14], it should be considered that the extraction procedure that defines GRSP as a mixture of compounds. Hence, due to the very complicated nature of this substance the chemical nature of 
glomalin has yet to be conclusively determined. However, it is extremely interesting how GRSP itself can affect soil quality and its physicochemical and biological properties.

GRSP (T-GRSP and EE-GRSP) are stable, water-insoluble and degradation-resistant molecules stabilizing soil aggregates and protecting them from disintegration $[15,16]$. The hydrophobic domains of the molecules are responsible for the difficulty in their extraction and their low solubility. On the one hand, such properties make GRSP very stable compounds, ideal for protecting soil aggregates from degradation. On the other hand, they are difficult to identify and establish the exact structure of these molecules [16].

Similarly, the physicochemical properties of soils may have a significant impact on the glomalin content in soil [12]. The brief literature review presented above clearly indicates that GRSP not only play an important role in the functioning of the symbiotic system between plant roots and AMF but they are also a very important fraction of soil OM determining the structural properties of soils and improving soil stability and quality [14].

Soil quality is concerned with physical, chemical and biological aspects and defines the capacity of agricultural soil to deliver multiple functions (productivity, nutrient cycling, water filtration, carbon sequestration and microbial diversity) [16-18]. This capacity can be depleted, resulting in degradation of the system by compaction, erosion or loss of soil OM. An index as described by Dexter [16] using S-theory was identified as a key metric of overall soil quality. Based upon the S-theory, the S-term offers a singular value which is considered reflective of overall soil physical quality, and the S-term can be considered suggestive of not only physical quality but also both chemical and biological quality. The S-theory proposes that soil physical properties and behaviour are essentially controlled by soil structure, which is expressed as pore size distribution. Thus, the S-Index offers a simple scale that has the same physical meaning regardless of soil type and can therefore be used to compare soil physical quality across soil types and spatial scales [18].

The aim of the study was to evaluate the changes in glomalin-related soil proteins (GRSP) content, microbial diversity and soil physical quality depending on the type of soil as the important determinants of soil quality. The connections and relations between the soil quality, physical parameters including $S$ Index and the glomalin-related soil proteins in context to maintenance of soil health and quality will be looking for.

\section{Materials and Methods}

\subsection{Field Experiment and Soil Samples}

The study was based on a long-term stationary field microplot experiment established in 1880-1881 [19]. The experiment is located in areas belonging to the Institute of Soil Science and Plant Cultivation-State Research Institute in Pulawy, Poland (geographical coordinates of the experiment $51^{\circ} 24^{\prime} 52.9^{\prime \prime} \mathrm{N} 21^{\circ} 57^{\prime} 34.5^{\prime \prime}$ E). Plots of $12 \mathrm{~m}^{2}$ and $1 \mathrm{~m}$ deep were separated with concrete walls and filled with soil. The soil was placed in microplots in accordance with the natural profile systems. The soil profiles came from the surrounding area of Pulawy, Poland [19]. Soil horizons were placed in accordance their natural arrangement, to specially prepared concreted micro-parcels. Microplots do not have a concrete bottom in order to ensure contact of the soil with the natural substrate. The soil profiles were collected without destroying the soil structure, preserving the natural soil horizons. From the beginning of the experiment, all soils were treated equally including the same cultivated plant, agriculture management (hand tillage; hand-picked weeds, digging soil with a hoe), irrigation and fertilization. The number of microplots were presented in Figure 1A. An example of a micro plot was presented in Figure 1B. 


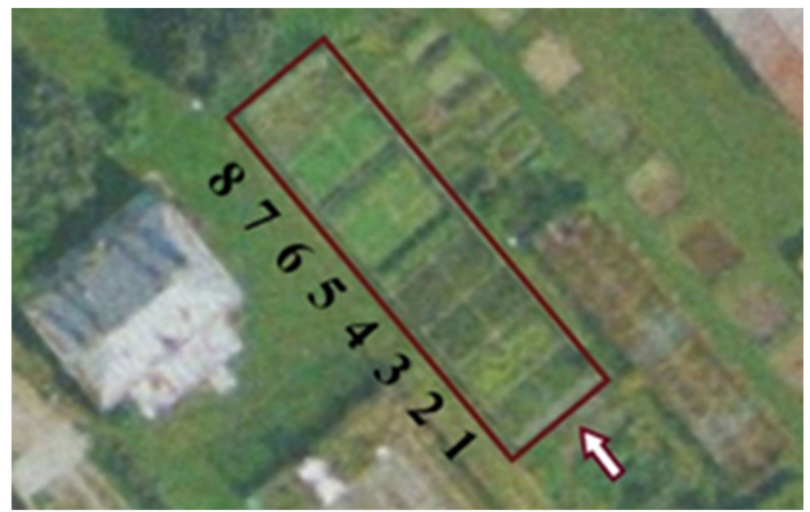

Plot numbers:

M-microplot

M1; Brunic Arenosol (Distric I)

M2; Rendzic Leptosol

M3; Fluvic Cambisol

M4; Haplic Cambisol (Eutric I)

M5; Gleyic Phaeozem

M6; Brunic Arenosol (Dystric II)

M7; Haplic Cambisol (Eutric II)

M8; Haplic Cambisol (Dystric)

(A)

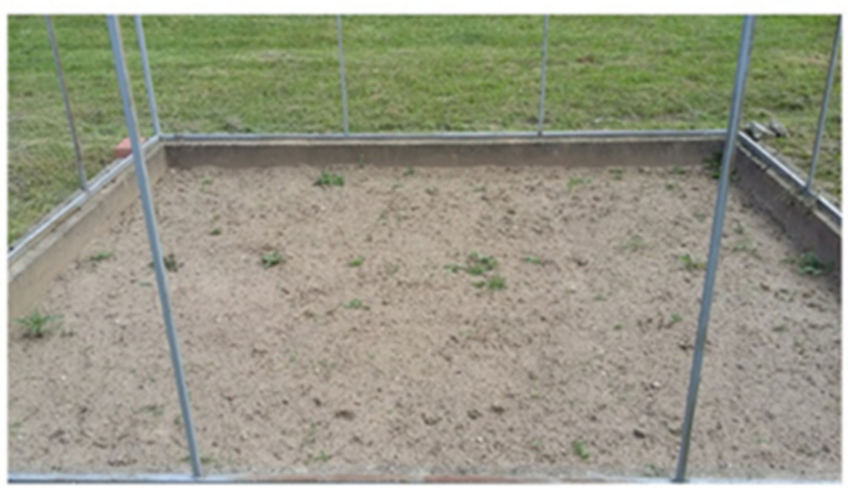

(B)

Figure 1. The microplots experiment (A). The microplots are presented in the period before sowing, in early spring, April (B). (photo by J. Grządziel, materials from Ph.D. thesis), [5].

Potassium and phosphorus fertilization was applied before sowing in the amount of $100 \mathrm{~kg} \mathrm{~K}_{2} \mathrm{O}$ and $80 \mathrm{~kg} \mathrm{P} \mathrm{P}_{2} \mathrm{O}_{5} / \mathrm{ha}$. Nitrogen fertilization $90 \mathrm{~kg} \mathrm{~N} / \mathrm{ha}$ was used on two dates: $50 \mathrm{~kg} \mathrm{~N} / \mathrm{ha}$ before sowing and $40 \mathrm{~kg} \mathrm{~N} / \mathrm{ha}$ during the time of firing. Soil samples were taken every year in April when there were no plants. In this publication, the authors decided to analyze the soil itself without plants. The same soil samples had previously been tested in the context of the biodiversity measure $[8,10]$.

Samples of bulk soil were collected in April 2016-2018, annually as three biological replicates from each plot at a depth of $0-15 \mathrm{~cm}$ (a total of 15 sampling occasions with an each microplot; five for each biological replicates). Figure 2 shows an exemplary scheme of sampling from the M1 plot. Subsequently, soil samples were, sieved through a $2 \mathrm{~mm}$ sieve, and stored at $-20^{\circ} \mathrm{C}$ prior to DNA extraction and at $4{ }^{\circ} \mathrm{C}$ until analysis of biological activity. Moreover, the soils always were under the same weather conditions and hand tillage management.

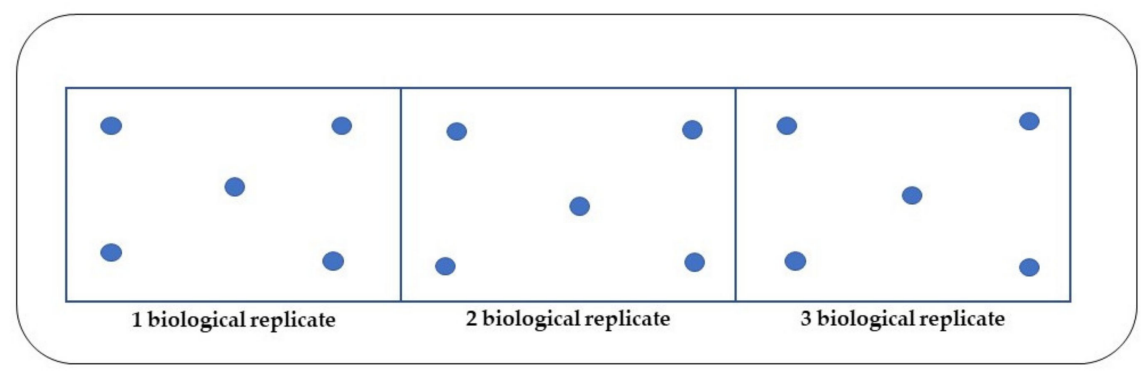

Figure 2. The scheme of soil sampling from the M1 plot.

The microplot experiment represents the most typical and common soil types of agricultural soils found in Poland [6]. Three soils were characterized by high organic carbon, $\mathrm{pH}$ 7.3-7.5 and good quality 
for plant cultivation: Rendzic Leptosol, Gleyic Phaeozem and Fluvic Cambisol. Another two soils, Haplic Cambisol (Eutric II) and Haplic Cambisol (Dystric), exhibited low organic carbon, pH 5.4-5.6 and relatively good conditions for cultivation of certain plants. The last three soils were acidic ( $\mathrm{pH}$ 4.0-4.7), characterized by low organic carbon, and poor quality for cultivation: Brunic Arenosol (Dystric I), Brunic Arenosol (Dystric II) and Haplic Cambisol (Eutric I) (Table 1). The full description of the experiment along with engravings can be found in the supplement for the paper Grzadziel and Gałąza [11]; https://www.frontiersin.org/articles/10.3389/fmicb.2019.00006/full\#supplementarymaterial. The main advantage of this microplot experiment is that all soils are collected in the very small area, and are subjected to the same conditions (geographical location, weather, the same climate etc.). Since 1979, the plots have been planted mostly with cereals as the main crop with mineral fertilizers, and mainly mustard, phacelia or leguminous plants as the second crop. In 1984, the plots were fertilized with compost (80 t/ha) under potatoes [8]. In 2016-2018, the same plant species (winter wheat) was always grown in all plots at the same time and the soil received the same NPK fertilization.

The microplot experiment has been described in detail in the papers by Czaban et al. [8], Grządziel and Gałązka [10,11], Grządziel et al. [9] and Siebielec et al. [20].

Soil types were determined in accordance with the World Reference Base (WRB), whereas soil texture classes were determined on the basis of the United States Department of Agriculture (USDA) Soil Texture Classes System (Table 1). Based on the S Index, these soils can be divided into a few groups: very poor soil physical quality $(S \geq 0.025$, Brunic Arenosol Distric I), poor soil physical quality ( $S \leq 0.02$, Brunic Arenosol Distric II), good soil physical quality [0.050 $>S \geq 0.035$, Fluvic Cambisol, Rendzic Leptosol, Haplic Cambisol (Dystric), Haplic Cambisol (Eutric II), Haplic Cambisol (Eutric I)] and very good soil physical quality ( $\mathrm{S} \geq 0.050$, Gleyic Phaeozem). It was closely related to the total glomalin related soil protein content. This division on the basis of the $S$ index value was closely related to the GRSP content (Table 1).

The meteorological conditions during the growing seasons (2016-2018) was presented in Table 2. The average annual April temperature reaches $+8.7^{\circ} \mathrm{C}$. The annual April rainfall is $42.9 \mathrm{~mm}$. The snow cover lasts 80-85 days and the vegetation period lasts 210-220 days a year.

\subsection{Clay Dispersion Measurements}

The method used for determination of readily dispersible clay (RDC) in normalized turbidity units (NTU/(g/L)), is that described by Czyż and Dexter [21]. The amounts of total clay (TC) and RDC were determined by a turbidimetric method using a standard procedure. The stability of soils was calculated as 1-(RDC/TC) NTU/(g/L).

\subsection{Soil Water Retention}

Soil water retention curves were measured with undisturbed soil samples using standard sand boxes (Eijkelkamp, Giesbeek, The Netherlands) for low levels of water potential (10, 20, 40 and $100 \mathrm{hPa})$ and pressure plates (Soil Moisture Inc., Santa Barbara, CA, USA) for high levels of water potential (250, $500,1000,2000,4000,8000$ and $15,000 \mathrm{hPa}$ ). The mean values of the water content corresponding to each level of water potential were fitted to the van Genuchten equation [22].

\subsection{Soil Physical Quality S-Index}

Soil physical quality S-Index, as the slope the of the water retention curve at its inflection point, was calculated based on the equation described by Dexter [16] and Dexter and Czyż [17]. S-Index is a measure of soil microstructure which controls many of the soil physical properties and it is hoped that it may be useful for the assessment of soil quality. Based on experience in a wide range of soil properties and on experimental data of various soils, Dexter presented categories of soil physical quality 'S' [16]. The S-Index is derived from the relationship between the gravimetric soil water content and the natural $\log$ of matric tension. This is calculated as the slope of the soil water retention curve (SWRC). 
Table 1. Classification and basic characteristic of soils used in the experiment (the soils were grouped according to the S Index value from the lowest value to the highest).

\begin{tabular}{|c|c|c|c|c|c|c|c|c|c|c|c|c|c|}
\hline \multirow[b]{2}{*}{ Soil Type ${ }^{1}$} & \multirow[b]{2}{*}{ Symbol } & \multirow[b]{2}{*}{ Plot Number } & \multirow[b]{2}{*}{$\begin{array}{l}\text { Soil Texture } \\
\text { Class }^{2}\end{array}$} & \multicolumn{3}{|c|}{ Particle Size Distribution [\%] } & \multirow[b]{2}{*}{ S-Index } & \multirow[b]{2}{*}{ T-GRSP } & \multirow[b]{2}{*}{$\mathrm{C}[\%]$} & \multirow[b]{2}{*}{$\mathbf{N}[\%]$} & \multirow[b]{2}{*}{$\mathrm{C} / \mathrm{N}$} & \multirow[b]{2}{*}{ RDC/TC } & \multirow[b]{2}{*}{$\mathrm{pH}$} \\
\hline & & & & $\begin{array}{c}\text { Sand } \\
(2.0-0.05 \mathrm{~mm})\end{array}$ & $\begin{array}{c}\text { Silt } \\
(0.05-0.002 \mathrm{~mm}) \\
\end{array}$ & $\begin{array}{c}\text { Clay } \\
(<0.002 \mathrm{~mm})\end{array}$ & & & & & & & \\
\hline Brunic Arenosol (Dystric I) & BA (I) & M1 & loamy sand & 78 & 21 & 1 & 0.018 & 2.87 & 0.654 & 0.063 & 10.38 & 0.313 & 4.0 \\
\hline Brunic Arenosol (Dystric II) & BA (II) & M6 & loamy sand & 85 & 14 & 1 & 0.025 & 3.07 & 0.522 & 0.046 & 11.35 & 0.288 & 4.5 \\
\hline Fluvic Cambisol & FC & M3 & sandy loam & 52 & 34 & 14 & 0.046 & 4.59 & 1.364 & 0.106 & 12.87 & 0.054 & 7.5 \\
\hline Rendzic Leptosol & RL & M2 & sandy loam & 60 & 32 & 8 & 0.050 & 4.43 & 1.967 & 0.115 & 17.10 & 0.084 & 7.3 \\
\hline Haplic Cambisol (Dystric) & $\mathrm{HC}(\mathrm{D})$ & M8 & $\begin{array}{l}\text { fine sandy } \\
\text { loam }\end{array}$ & 71 & 27 & 2 & 0.056 & 3.79 & 0.916 & 0.090 & 10.18 & 0.126 & 5.6 \\
\hline Haplic Cambisol (Eutric II) & $\mathrm{HC}(\mathrm{EII})$ & M7 & $\begin{array}{c}\text { medium } \\
\text { sandy loam }\end{array}$ & 58 & 38 & 4 & 0.058 & 4.68 & 0.858 & 0.091 & 9.43 & 0.098 & 5.4 \\
\hline $\begin{array}{l}\text { Haplic Cambisol (Eutric } \\
\text { I)-developed from loess }\end{array}$ & $\mathrm{HC}(\mathrm{EI})$ & M4 & $\begin{array}{l}\text { fine sandy } \\
\text { loam }\end{array}$ & 49 & 48 & 3 & 0.060 & 4.04 & 0.842 & 0.089 & 9.46 & 0.179 & 4.7 \\
\hline Gleyic Phaeozem & GPh & M5 & $\begin{array}{l}\text { fine sandy } \\
\text { loam }\end{array}$ & 54 & 43 & 3 & 0.076 & 6.33 & 3.101 & 0.225 & 13.78 & 0.095 & 7.4 \\
\hline
\end{tabular}

${ }^{1}$ Determined in accordance with the World Reference Base for Soil Resources (WRB, 2008). ${ }^{2}$ Determined on the basis of the USDA (United States Department of Agriculture) Natural Resources Conservation Service; Soil Taxonomy A Basic System of Soil Classification for Making and Interpreting Soil Surveys. Particle size distribution [\%]—Casagrande method modified by Prószyński [PN—R 04032:1998] T-GRSP—total glomalin related soil proteins [mg/g d.m. of soil]. C [\%], N [\%]-Determinations of carbon and nitrogen by C-N Analyzer RDC/TC-readily dispersible clay (RDC)/total clay (TC). $\mathrm{pH} \mathrm{H} \mathrm{H}_{2} \mathrm{O}$-potentiometric method-[PN-ISO 10390:1997]. S-Index classification: $\mathrm{S} \geq 0.050$ very good soil physical quality; $0.050>\mathrm{S} \geq$ 0.035 good soil physical quality; $0.035>\mathrm{S} \geq 0.020$ poor soil physical quality; $0.020>\mathrm{S}$ very poor soil physical quality. 
Table 2. Meteorological conditions during the growing seasons (2016-2018).

\begin{tabular}{|c|c|c|c|c|c|c|c|c|c|c|c|c|c|}
\hline & \multicolumn{13}{|c|}{ Average Air Temperature $\left({ }^{\circ} \mathrm{C}\right)$} \\
\hline & $\mathbf{I}$ & II & III & IV & $\mathbf{V}$ & VI & VII & VIII & IX & $X$ & XI & XII & Year \\
\hline 2016 & 1.3 & 1.0 & 5.1 & 8.6 & 13.5 & 17.9 & 20.4 & 22.6 & 15.3 & 7.0 & 5.2 & 4.0 & 10.2 \\
\hline 2017 & -3.3 & 3.7 & 4.3 & 9.6 & 15.6 & 19.8 & 20.1 & 18.7 & 15.6 & 7.7 & 3.2 & 0.8 & 9.7 \\
\hline \multirow[t]{3}{*}{2018} & -4.6 & -1.1 & 6.2 & 7.9 & 14.7 & 18.9 & 19.4 & 20.1 & 14.1 & 9.5 & 4.6 & 2.5 & 9.4 \\
\hline & \multicolumn{13}{|c|}{ Sum of Precipitation (mm) } \\
\hline & I & II & III & IV & $\mathbf{V}$ & VI & VII & VIII & IX & $X$ & XI & XII & Year \\
\hline 2016 & 55.3 & 9.9 & 45.8 & 28.5 & 111.6 & 32.0 & 55.4 & 3.6 & 126.0 & 30.0 & 47.4 & 25.2 & 570.7 \\
\hline 2017 & 33.0 & 64.5 & 53.0 & 38.4 & 72.2 & 27.9 & 86.6 & 41.9 & 20.6 & 100.2 & 44.9 & 64.6 & 647.8 \\
\hline 2018 & 10.7 & 42.4 & 31.6 & 31.9 & 48.2 & 35.4 & 150.3 & 76.8 & 105.2 & 94.9 & 53.7 & 20.5 & 731.6 \\
\hline
\end{tabular}

\subsection{Microbial Communities and Enzymatic Analysis}

Microbiological counts were expressed as the number of colony-forming units (CFU) per gram of dry mass of soil (d. m.). The total number of bacteria (B) was determined by the dilution method on agarized soil extract. The total number of fungi was determined on Martin's medium [23]. Ammonifying bacteria (AM) were determined according to Rodina's method [24] and Azotobacter spp. according to Fenglerowa's method [25]. Microbial biomass was determined by the chloroform fumigation-extraction method according to Ghani et al. [26]. Enzymatic activity was determined spectrophotometrically: soil dehydrogenase activity using the TTC method (Polish Standard. PN-EN ISO 23753-1) [27], phosphatases activity by the $p$-NPP method [28].

\subsection{Glomalin Related Soil Proteins Content Analysis}

Glomalin related soil proteins content was determined as proposed by Wright et al. [29] with modifications described by Gałazka et al. [7]. GRSP concentrations were determined spectrophotometrically as both T-GRSP and EE-GRSP [24]. TG-GRSP was obtained by repeated extraction from $1 \mathrm{~g}$ of ground dry-sieved soil with $8 \mathrm{~mL}$ of $50 \mathrm{mM}$ citrate, $\mathrm{pH} 8.0$ at $121^{\circ} \mathrm{C}$ for $60 \mathrm{~min}$. The EE-GRSP protein was extracted from $1 \mathrm{~g}$ of ground dry-sieved soil with $8 \mathrm{~mL}$ of $20 \mathrm{mM}$ citrate, $\mathrm{pH} 7.0$ at $121^{\circ} \mathrm{C}$ for $30 \mathrm{~min}$. After each autoclaving cycle, the supernatant was removed by centrifugation at $4000 \mathrm{rpm}$ for $15 \mathrm{~min}$ and stored. Extracts from each cycle were pooled, centrifuged at $9000 \mathrm{rpm}$ for $5 \mathrm{~min}$ to remove soil particles and then analysed. Extracts from each replicate were pooled and analysed, and the protein in the supernatant was determined by the Bradford dye-binding assay with bovine serum albumin as the standard on a 96-plate reader (Victor Perkin Elmer, Waltham, MA, USA).

\subsection{Determination of Number of AMF Spores in Soils}

The total number of AMF spores was evaluated according to the Phillips and Hayman method [30]. Root mycorrhizal structures were stained with $0.05 \%(w / v)$ trypan blue. The number of AMF spores was determined in averaged samples of $100 \mathrm{~g}$ of air-dried soil $(2 \times 50 \mathrm{~g})$, while AMF spores separated on filters with mesh sizes of 150, 100 and $50 \mu \mathrm{m}$ were counted, which, when added together, give the number of spores in a soil sample.

\subsection{Total DNA Extraction from Soil}

Fresh soil samples were weighed; similar amounts (300-350 mg) were collected into $1.5 \mathrm{~mL}$ tubes and used to extract DNA with a FastDNA ${ }^{\mathrm{TM}}$ SPIN Kit for Soil (MP Biomedical) according to the manufacturer's instructions. The concentration and purity of extracted DNA were measured in a NanoDrop ${ }^{\mathrm{TM}} 1000$ Spectrophotometer (Thermo Scientific, Waltham, MA, USA). As a result, approximately $60 \mathrm{ng} / \mu \mathrm{L}$ DNA was obtained from each sample which corresponds to $17.5 \mu \mathrm{g}$ of DNA from $1 \mathrm{~g}$ of soil sample, with an A260/280 ratio of 1.4-1.6. For further experiments, each DNA sample was diluted to a final concentration of about $10 \mathrm{ng} / \mu \mathrm{L}$. 


\subsection{PCR Amplification}

Fragments of $16 \mathrm{~S}$ rRNA gene were amplified to perform genetic differentiation of the bacteria found in soils. To increase the specificity of the reaction, a two-step PCR method was performed. In the first step, a $1492 \mathrm{bp}$ fragment of the $16 \mathrm{~S}$ rRNA gene was amplified with primers 27F and 1492R. The PCR mixture (total $20 \mu \mathrm{L}$ volume) contained $4 \mu \mathrm{L}$ Silver Hot Start PCR MIX LOAD (Syngen Biotech, Poland), $0.15 \mu \mathrm{M}$ of each primer, $20 \mathrm{ng}$ of template DNA, and ultrapure water. Each primer set can be found in Table 3. The amplification products were used as templates for PCR-DGGE with two sets of primers. GC-338F and 518R were used to amplify the hypervariable V3 region of about 197 bp present in most of the Bacteria. Amplification of a $280 \mathrm{bp}$ product of Actinobacteria was performed with Act235F and Eub518R primers. The PCR mixture (total volume $50 \mu \mathrm{L}$ ) contained $25 \mu \mathrm{L}$ of DreamTaq Green PCR MasterMix (Thermo Scientific), $0.4 \mu \mathrm{M}$ of each primer, $2 \mu \mathrm{L}$ of diluted 16S rDNA PCR product, and ultrapure water. Detailed PCR parameters are presented in Table 4. Amplicons were confirmed by electrophoresis on $1 \%$ agarose gel stained with ethidium bromide in $1 \times$ TAE buffer using a GeneRuler 100 bp DNA Ladder (Thermo Scientific).

Table 3. Primers used in the experiment.

\begin{tabular}{|c|c|c|c|}
\hline Primer Set & Sequence $5^{\prime}-3^{\prime}$ & Target & Reference \\
\hline \multicolumn{4}{|c|}{ Bacteria-specific } \\
\hline $\begin{array}{c}27 \mathrm{~F} \\
1492 \mathrm{R}\end{array}$ & $\begin{array}{l}\text { >AGAGTTTGATCCTGGCTCAG } \\
\text { >GGTTACCTTGTTACGACTT }\end{array}$ & 16S rRNA gene & [31] \\
\hline $\begin{array}{l}\text { GC-338F } \\
\text { Eub518R }\end{array}$ & $\begin{array}{c}\text { >GC-clamp-ACTCCTACGGGAGGCAGCAG } \\
\text { >ATTACCGCGGCTGCTGG }\end{array}$ & V3 hypervariable region & [32] \\
\hline \multicolumn{4}{|c|}{ Actinobacteria-specific } \\
\hline $\begin{array}{l}\text { Actino235F } \\
\text { Eub518R }\end{array}$ & $\begin{array}{c}>\text { GC-clamp-CGCGGCCTATCAGCTTGTTG } \\
>\text { ATTACCGCGGCTGCTGG }\end{array}$ & 16S rRNA gene & [33] \\
\hline \multicolumn{4}{|c|}{ GC-clamp sequence } \\
\hline \multicolumn{3}{|c|}{ > CGCCCGCCGCGCGCGGCGGGCGGGGCGGGGGCACGGGGGG (40 nt) } & [32] \\
\hline
\end{tabular}

Table 4. PCR and PCR-DGGE amplification parameters.

\begin{tabular}{cccc}
\hline PCR Step & 16S rRNA PCR & V3 PCR-DGGE & Actino PCR-DGGE \\
\hline Initial denaturation & $95^{\circ} \mathrm{C}, 15 \mathrm{~min}$ & $95^{\circ} \mathrm{C}, 3 \mathrm{~min}$ & $95^{\circ} \mathrm{C}, 3 \mathrm{~min}$ \\
Denaturation & $95^{\circ} \mathrm{C}, 30 \mathrm{~s}$ & $95^{\circ} \mathrm{C}, 30 \mathrm{~s}$ & $95^{\circ} \mathrm{C}, 30 \mathrm{~s}$ \\
Annealing & $52^{\circ} \mathrm{C}, 60 \mathrm{~s}$ & $55^{\circ} \mathrm{C}, 30 \mathrm{~s}$ & $55^{\circ} \mathrm{C}, 30 \mathrm{~s}$ \\
Extension & $72{ }^{\circ} \mathrm{C}, 90 \mathrm{~s}$ & $72{ }^{\circ} \mathrm{C}, 30 \mathrm{~s}$ & $72{ }^{\circ} \mathrm{C}, 30 \mathrm{~s}$ \\
Final extension & $72^{\circ} \mathrm{C}, 7 \mathrm{~min}$ & $72^{\circ} \mathrm{C}, 5 \mathrm{~min}$ & $72^{\circ} \mathrm{C}, 5 \mathrm{~min}$ \\
Number of cycles & 35 & 32 & 32 \\
\hline
\end{tabular}

\subsection{Denaturing Gradient Gel Electrophoresis (DGGE)}

Amplicons were separated using the DCode ${ }^{\mathrm{TM}}$ Universal Mutation Detection System (Bio-Rad Laboratories, Hercules, CA, USA) with modifications to the method described by Muyzer et al. [32]. Equal quantities of DNA (650 ng) were loaded into $8 \%(w / v)$ PLA gels ( $40 \%$ acrylamide/bis solution, $37.5: 1$ ) in $1 \times$ TAE buffer. The denaturing gradient for Bacteria-V3 amplicons ranged from $40 \%$ to $60 \%$ and for Actinobacteria from $50 \%$ to $70 \%$, assuming that $100 \%$ is $7 \mathrm{M}$ urea and $40 \%(v / v)$ deionized formamide. Electrophoresis was performed at $55 \mathrm{~V}$ for $16 \mathrm{~h}$ (Table 3). A constant temperature of $60^{\circ} \mathrm{C}$ was maintained. Gels were stained for 30 min using 10,000 times-diluted SYBR ${ }^{\circledR}$ Gold Nucleic Acid Gel Stain (Thermo Scientific) and visualized on a UV transilluminator. Images were then analysed using Quantity One 4.6.9 software (Bio-Rad). 


\subsection{Community-Level Physiological Profiling (CLPP) Analysis Using Biolog EcoPlates}

The CLPP was evaluated using Biolog EcoPlates (Biolog Inc., Hayward, CA, USA) with 31 different carbon sources [34]. The soil suspension for the inoculation of wells in microplates was prepared as follows. One gram of soil was weighed and transferred to a conical flask holding $99 \mathrm{~cm}^{3}$ sterile $0.9 \% \mathrm{NaCl}$, vortexed for $30 \mathrm{~min}$ at $150 \mathrm{rpm}$ and at $25^{\circ} \mathrm{C}$, after which the samples were cooled for $30 \mathrm{~min}$ to $4{ }^{\circ} \mathrm{C}$. After that, $120 \mathrm{~mm}^{3}$ was transferred to each well of an EcoPlate and incubated in the dark at $25^{\circ} \mathrm{C}$ for $120 \mathrm{~h}$. The experiment included three replications. The results were read on a MicroStation ID system (Biolog Inc., Hayward, CA, USA). The extent to which carbon sources were used was determined through the reduction of colourless tetrazolium chloride (TTC) to red triphenyl-formasane (TPF) [34,35]. The intensity of colour development was recorded at $\lambda=590 \mathrm{~nm}$ for a period of $120 \mathrm{~h}$ at $24 \mathrm{~h}$ intervals. The activities of soil microorganisms are based on all carbon sources and on grouped sources defined as amines and amides, amino acids, carbohydrate, carboxylic acids and polymers. The results were expressed as average well-colour development (AWCD) and Shannon-Wiener $\left(H^{\prime}\right)$ index.

\subsection{Statistical Analysis}

Statistical analyses were performed using the packetSTATISTICA.PL (10) (StatSoft. Inc., Tulsa, OK, USA). The variables had a normal distribution. Collected data were subjected to analysis of variance (ANOVA) for comparison of means. Significant differences were calculated according to Tukey's post hoc test at a significance level of $p<0.05$. Cluster analysis, including grouping of the treatments and features, was performed on standardized data ( 95 carbon sources in triplicate) from the average absorbance values at $120 \mathrm{~h}$ (Biolog EcoPlate). The dendrogram was prepared with scaled bond distances on the axis (Ward's method), and the boundary was marked according to Sneath's criteria. AWCD was evaluated according to the formula $\mathrm{AWCD}=\Sigma(\mathrm{C}-\mathrm{R}) / 95$, where $\mathrm{C}$ is the absorbency in each well and $\mathrm{R}$ is the absorbency in the control well. The Shannon-Wiener $\left(H^{\prime}\right)$ index was evaluated in accordance with the formula $H^{\prime}=-\Sigma \mathrm{pi}(\operatorname{lnpi})$, where pi is the ratio of the absorbance of each well to the absorbency of all wells. The results were also submitted to principal component analysis (PCA). All soil quality parameters tested in this study were used as variables in the PCA analysis. The PCA analysis was performed using the packet STATISTICA.PL (10), the data were standardized.

\section{Results}

\subsection{Physical and Chemical Properties of Soil}

The physical and chemical properties of soils are presented in Table 1. The carbon content of soil samples ranged from 0.522\% (Brunic Arenosol Dystric II) to 3.101\% (Gleyic Phaeozem). The nitrogen content in soil samples ranged from 0.046\% (Brunic Arenosol Dystric II) to $0.225 \%$ (Gleyic Phaeozem). The RDC/TC ratio was highest in Brunic Arenosol Dystric I (0.313) and lowest in Fluvic Cambisol (0.054).

Based on the parameters of van Genuchten, the S-Index was calculated (Table 5). Gleyic Phaeozem was characterized by the highest value of the S-Index (0.076) — very good SPQ (Soil Physical Quality). A higher S-Index value also corresponded to a higher glomalin content (Table 1). The highest GRSP content was found in Gleyic Phaeozem ( $6.33 \mathrm{mg} / \mathrm{g} \mathrm{d}$.m. soil), while the lowest was found in Brunic Arenosol (Dystric I) - $2.87 \mathrm{mg} / \mathrm{g} \mathrm{d}$ d.m. of soil; this value corresponded to the lowest S-Index for this soil (0.018) - very poor SPQ. 
Table 5. Mean values of parameters of the van Genuchten equation [20] and of the S-Index (the soils were grouped according to the S Index value from the lowest value to the highest).

\begin{tabular}{|c|c|c|c|c|c|c|}
\hline Soil Type & $\begin{array}{c}\theta s \\
(\mathrm{~kg} / \mathrm{kg})\end{array}$ & $\begin{array}{c}\theta \mathbf{r} \\
(\mathrm{kg} / \mathrm{kg})\end{array}$ & $\begin{array}{c}\alpha \\
\left(\mathrm{hPa}^{-1}\right)\end{array}$ & $\begin{array}{l}n \\
(-)\end{array}$ & $\begin{array}{l}m \\
(-)\end{array}$ & $\begin{array}{l}S \\
(-)\end{array}$ \\
\hline Brunic Arenosol (Dystric I) & 0.2528 & 0.0118 & 0.0101 & 1.6889 & 0.4079 & -0.0185 \\
\hline Brunic Arenosol (Dystric II) & 0.2360 & 0.0202 & 0.0116 & 1.5755 & 0.3652 & -0.0250 \\
\hline Fluvic Cambisol & 0.2528 & 0.0349 & 0.0015 & 1.6889 & 0.4079 & -0.0456 \\
\hline Rendzic Leptosol & 0.2804 & 0.0504 & 0.0077 & 1.8752 & 0.4667 & -0.0501 \\
\hline Haplic Cambisol (Dystric) & 0.2492 & 0.0349 & 0.0101 & 1.6646 & 0.3992 & -0.0562 \\
\hline Haplic Cambisol (Eutric II) & 0.2456 & 0.0336 & 0.0067 & 1.6403 & 0.3903 & -0.0581 \\
\hline Haplic Cambisol (Eutric I) & 0.2540 & 0.0252 & 0.0067 & 1.6970 & 0.4107 & -0.0603 \\
\hline Gleyic Phaeozem & 0.2684 & 0.0807 & 0.0101 & 1.7942 & 0.4426 & -0.0764 \\
\hline
\end{tabular}

Explanation: $\theta \mathrm{s}-$ water content at saturation; $\theta \mathrm{r}$-residual water content; $\alpha$-adjustable scaling factor; $\mathrm{m}, \mathrm{n}$-adjustable shape factors; $\mathrm{S}$ - soil physical quality index.

\subsection{GRSP Content}

Based on an ANOVA analysis, it was found that both the type of soil and the year of sampling were significant in assessing the soil's biological activity (Table 6). As variables in the analysis, the following activities were chosen: T-GRSP and EE-GRSP content, enzymatic activity, total number of bacteria, total number of fungi and indicators of soil functional metabolism evaluation on the example of Biolog EcoPlate analysis. Detailed information is presented in Table 6.

Table 6. Results of an ANOVA analysis of variance $(p \leq 0.05)$ for the entire data set. Multidimensional significance tests. Parameterization with sigma-restrictions-decomposition of effective hypotheses.

\begin{tabular}{cccc}
\hline & Wilks Value & F Value & $p$ \\
\hline Type of soil & 0.000 & 35.34 & 0.000 \\
Year & 0.152 & 6.97 & 0.000 \\
Type of soil_Year & 0.005 & 2.53 & 0.000 \\
\hline
\end{tabular}

The concentrations of T-GRSP and EE-GRSP depended primarily on the type of soil (Table 7). The highest concentrations of T-GRSP were found in Gleyic Phaeozem which was also characterized by a higher organic carbon $\left(\mathrm{C}_{\mathrm{org}}\right)$ content $(3.1 \%)$. In addition, a high glomalin content was found in the following soils: Rendzic Leptosol, Fluvic Cambisol and Haplic Cambisol (Eutric II) (4.43, 4.59 and $4.68 \mathrm{mg} / \mathrm{g}$ d.m. of soil, respectively) (Table 5). Soils with a low T-GRSP content were: Brunic Arenosol (Dystric I), Brunic Arenosol (Dystric II), and Haplic Cambisol (Dystric) (2.87, 3.07 and 3.79 mg/g d.m. of soil, respectively). The T-GRSP and EE-GRSP content was also strongly associated with the type of soil. The highest EEG-GRSP content was found in Haplic Cambisol (Eurtic I), Gleyic Phaeozem and Haplic Cambisol (Eutric II), (2.31, 2.38 and $2.44 \mathrm{mg} / \mathrm{g}$ d.m. of soil, respectively) (Table 7).

The highest number of AMF spores was found in Haplic Cambisol (Eutric II), Haplic Cambisol (Dystric) and Fluvic Cambisol (Table 8). A different AMF spore content was also found depending on the diameter of the spores. The total number of $50 \mu \mathrm{m}$ diameter spores was highest in Haplic Cambisol (Dystric), but the number of $150 \mu \mathrm{m}$ diameter spores was highest in Haplic Cambisol (Eutric II). The lowest number of AMF spores was found in Brunic Arenosol (Distric I). 
Table 7. Total and easily extractable glomalin related soil proteins content in different soil types (the soils were grouped according to the S Index value from the lowest value to the highest).

\begin{tabular}{ccccc}
\hline \multicolumn{5}{c}{ Total Glomalin Related Soil Proteins (T-GRSP), (mg/g d.m. of Soil) } \\
\hline Year & $\mathbf{2 0 1 6}$ & $\mathbf{2 0 1 7}$ & $\mathbf{2 0 1 8}$ & Mean \\
\hline Brunic Arenosol (Dystric I) & 3.27 & 3.23 & 2.12 & $2.87^{\mathrm{c}}$ \\
Brunic Arenosol (Dystric II) & 2.58 & 3.50 & 3.14 & $3.07^{\mathrm{c}}$ \\
Fluvic Cambisol & 4.56 & 4.49 & 4.71 & $4.59^{\mathrm{b}}$ \\
Rendzic Leptosol & 5.13 & 4.56 & 3.60 & $4.43^{\mathrm{b}}$ \\
Haplic Cambisol (Dystric) & 3.92 & 4.03 & 3.45 & $3.79^{\mathrm{b}, \mathrm{c}}$ \\
Haplic Cambisol (Eutric II) & 4.68 & 4.82 & 4.56 & $4.68^{\mathrm{b}}$ \\
Haplic Cambisol (Eutric I) & 4.23 & 4.25 & 3.65 & $4.04^{\mathrm{b}}$ \\
Gleyic Phaeozem & 6.43 & 6.59 & 5.98 & $6.33^{\mathrm{a}}$ \\
\hline Easily Extractable Glomalin Related Soil Proteins (EE-GRSP), (mg/g d.m. of Soil) \\
\hline Brunic Arenosol (Dystric I) & 1.72 & 1.54 & 1.62 & $1.63^{\mathrm{c}}$ \\
Brunic Arenosol (Dystric II) & 1.72 & 1.77 & 1.54 & $1.67^{\mathrm{c}}$ \\
Fluvic Cambisol & 2.00 & 2.00 & 1.91 & $1.97^{\mathrm{c}}$ \\
Rendzic Leptosol & 2.46 & 2.21 & 2.06 & $2.24^{\mathrm{a}}$ \\
Haplic Cambisol (Dystric) & 1.95 & 2.10 & 1.97 & $2.00^{\mathrm{b}}$ \\
Haplic Cambisol (Eutric II) & 2.67 & 2.46 & 2.18 & $2.44^{\mathrm{a}}$ \\
Haplic Cambisol (Eutric I) & 2.43 & 2.29 & 2.22 & $2.31^{\mathrm{a}}$ \\
Gleyic Phaeozem & 2.32 & 2.58 & 2.25 & $2.38^{\mathrm{a}}$ \\
\hline
\end{tabular}

Treatment means separated by different letters are significantly different (Tukey's mean separation test, $p<0.05$ ); average for years 2016-2018 $(n=9)$

Table 8. Number of AMF spores in different soil types (the soils were grouped according to the S Index value from the lowest value to the highest). Treatment means separated by different letters are significantly different (Tukey's mean separation test, $p<0.05)$; average for years 2016-2018 $(n=9)$.

\begin{tabular}{ccccc}
\hline \multirow{2}{*}{ Soil Type } & Total Number of All Spores & \multicolumn{3}{c}{ Total Number by Spore Diameter } \\
\cline { 3 - 5 } & & $\mathbf{5 0} \boldsymbol{\mu \mathbf { m }}$ & $\mathbf{1 0 0} \boldsymbol{\mu \mathbf { m }}$ & $\mathbf{1 5 0} \boldsymbol{\mu \mathbf { m }}$ \\
\hline Brunic Arenosol (Dystric I) & $188^{\mathrm{d}}$ & $126^{\mathrm{c}}$ & $54^{\mathrm{c}}$ & $8^{\mathrm{c}}$ \\
\hline Brunic Arenosol (Dystric II) & $406^{\mathrm{c}}$ & $296^{\mathrm{b}}$ & $92^{\mathrm{c}}$ & $18^{\mathrm{b}}$ \\
\hline Fluvic Cambisol & $534^{\mathrm{a}}$ & $312^{\mathrm{b}}$ & $184^{\mathrm{a}}$ & $38^{\mathrm{a}}$ \\
\hline Rendzic Leptosol & $374^{\mathrm{c}}$ & $284^{\mathrm{b}}$ & $76^{\mathrm{c}}$ & $14^{\mathrm{b}}$ \\
\hline Haplic Cambisol (Dystric) & $592^{\mathrm{a}}$ & $396^{\mathrm{a}}$ & $172^{\mathrm{a}}$ & $24^{\mathrm{b}}$ \\
\hline Haplic Cambisol (Eutric II) & $586^{\mathrm{a}}$ & $324^{\mathrm{b}}$ & $204^{\mathrm{a}}$ & $58^{\mathrm{a}}$ \\
\hline Haplic Cambisol (Eutric I) & $464^{\mathrm{b}}$ & $360^{\mathrm{b}}$ & $88^{\mathrm{c}}$ & $16^{\mathrm{c}}$ \\
\hline Gleyic Phaeozem & $468^{\mathrm{b}}$ & $308^{\mathrm{b}}$ & $116^{\mathrm{b}}$ & $44^{\mathrm{a}}$ \\
\hline
\end{tabular}

\subsection{Microbial Diversity}

The microbiological diversity differed depending on the type of soil. As a result of PCR-DGGE analysis, two separate fingerprint images were obtained (Figure 3A,B).

Despite the high background signal generated by the large amount of DNA applied to a gel, there can be seen clearly distinct bands, which are characteristic for certain soils. Although both sets of primers generated similar results, dividing samples into two (Figure 4A) or three (Figure 4B) main groups, based on the results from the clustering, it can be observed that the use of Actinobacteria-specific primers resulted in more discriminating results. Each of these methods put together good-quality soils, while acidic, poor-quality soils were grouped into a separate cluster, providing the background for subsequent analyses. 


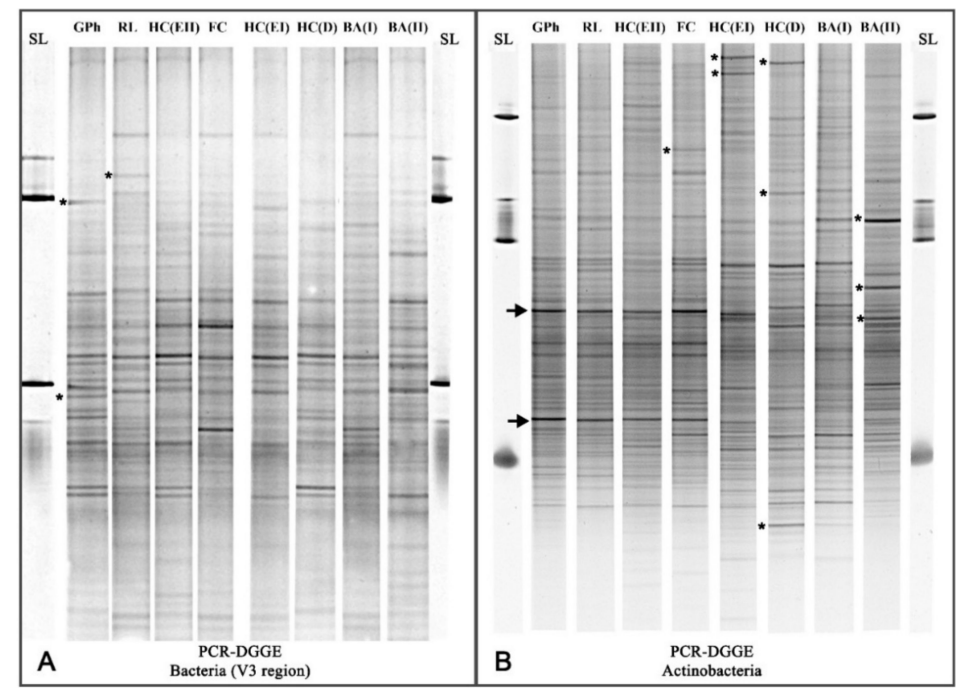

Figure 3. PCR-DGGE fingerprinting of $16 \mathrm{~S}$ rRNA gene: (A) Bacteria V3 regions of $16 \mathrm{~S}$ rRNA gene; (B) Actinobacteria regions of 16S RNA gene. SL-unrelated standard lanes. Bands that are unique for an indicated lane are marked with an asterisk. Two examples of bands that are specific only to good-quality soils are marked with an arrow. The soil symbols were given in Table 1.
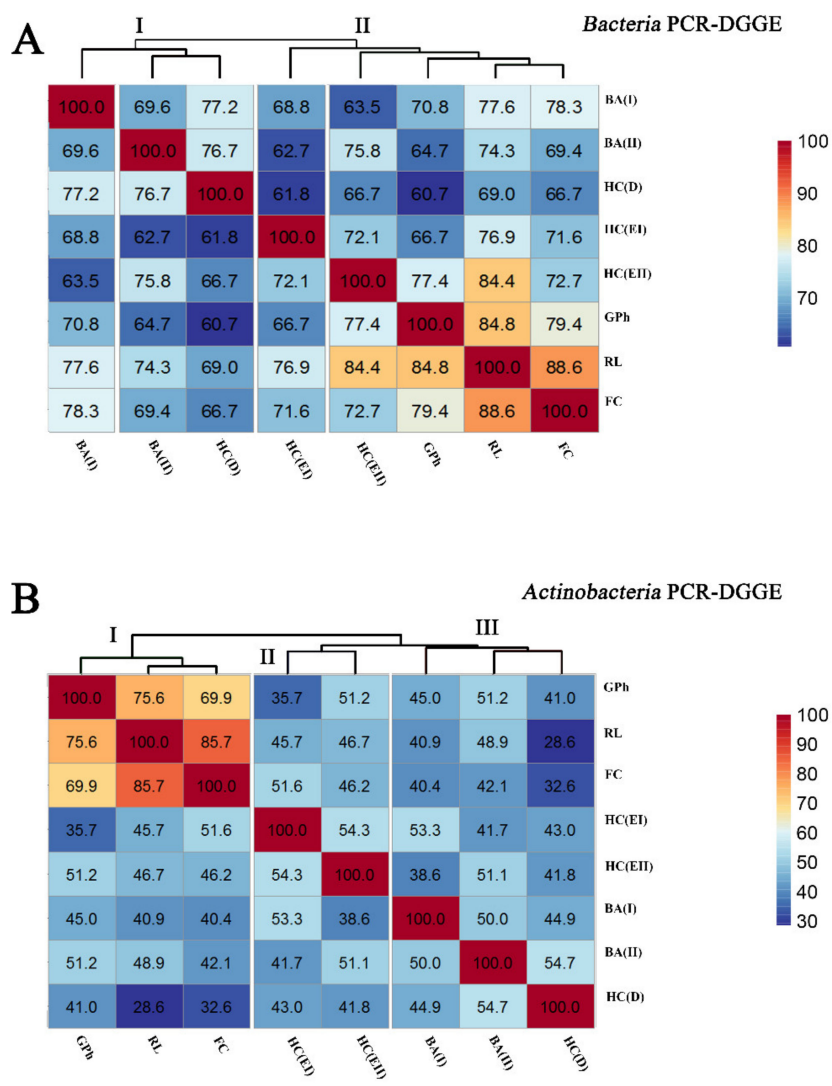

Figure 4. Similarity matrix of PCR-DGGE fingerprint with cluster analysis. Scale bar represents similarity in percentages: from $\sim 60 \%$ to $100 \%$ (A) and from $\sim 30 \%$ to $100 \%$ (B).

The results of our study show that not only are biochemical differences detectable in different soil types, but also the soil microbiome differs significantly among microplots. The result is not only a wide genetic diversity between samples using universal primers, but also considerable variation within the phylum Actinobacteria. These observations are essential, notably proving the soil buffering capacity. In such a complex biological material as soil, it is important to adjust the amplicon quantity loaded 
into a gel, at the same time remembering that the more PCR products there are, the more the band smearing effect is observed. This issue is caused by many factors, for example interactions between molecules, formation of single-stranded DNA during PCR, and electrophoresis [36].

\subsection{Biological Activity of Soil}

The basic enzymatic activity (dehydrogenase activity, acid and alkaline phosphatase activities) are presented on Figure 5. The enzymatic activity was strictly dependent on the type of soil and year. The highest dehydrogenase activity was found in Gleyic Phaeozem and the lowest in Brunic Arenosol (Dystric I and II). The highest alkaline phosphatase activity was observed in Gleyic Phaeozem. Very slight changes of enzymatic activities were observed also in years. In general, soils maintained enzymatic activity in the years 2016-2018 at a similar level, which indicates a stabilized microbiome of soils.

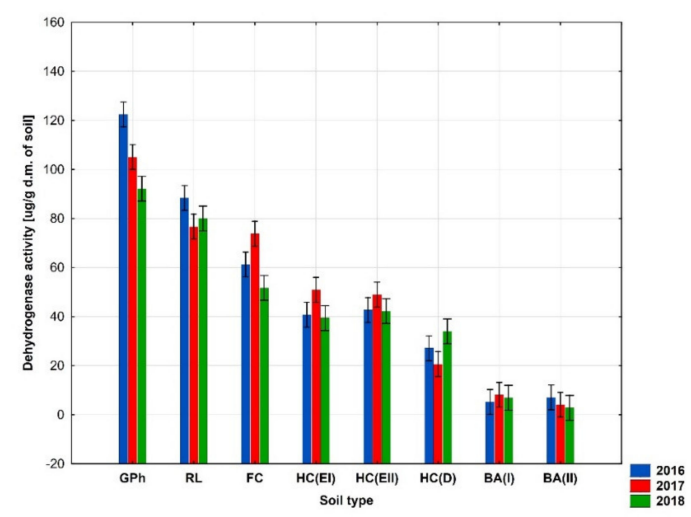

(A)

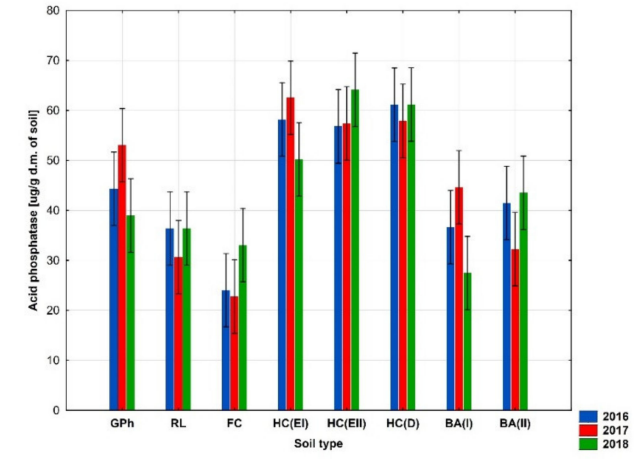

(B)

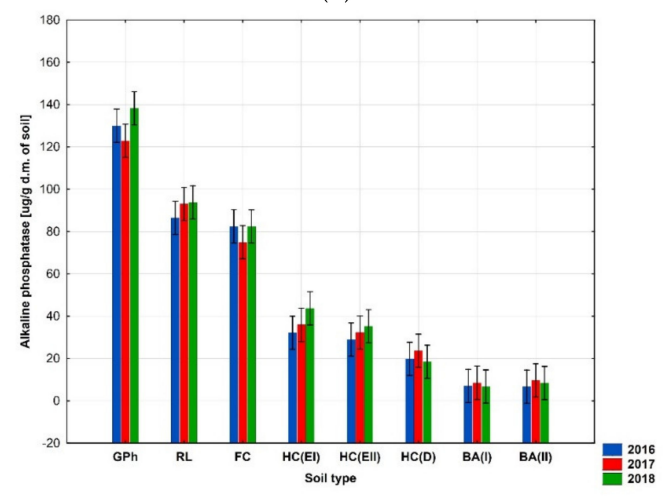

(C)

Figure 5. Enzymatic activities in soil, ANOVA analysis (the soils were organised in this case from highest to lowest soil quality): (A) Dehydrogenase activity; (B) Acid phosphatase activity; (C) Alkaline phosphatase activity. 
The highest content of microbial biomass of carbon (MBC) was observed in Gleyic Phaeozem and the lowest in Haplic Cambisol (Eurtic II) (Figure 6). The highest content of microbial biomass of nitrogen (MBN) was observed in Gleyic Phaeozem, but equally was also high in Rendzic Laptosol and Fluvic Cambisol.

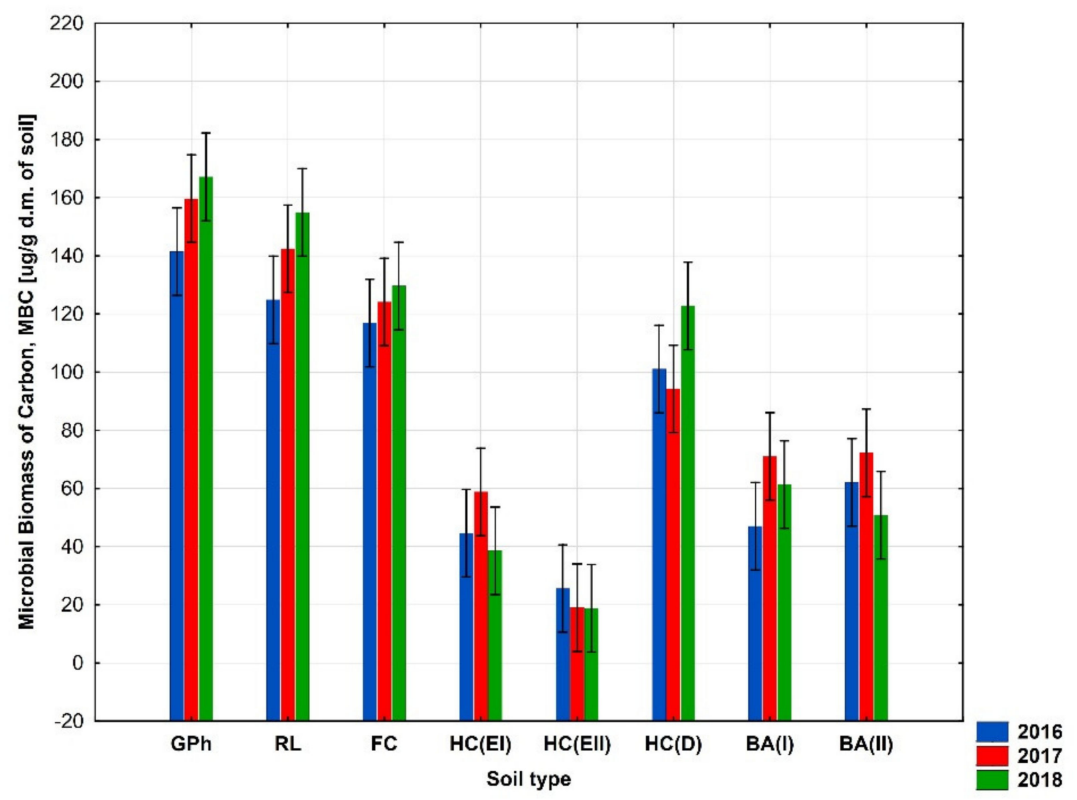

(A)

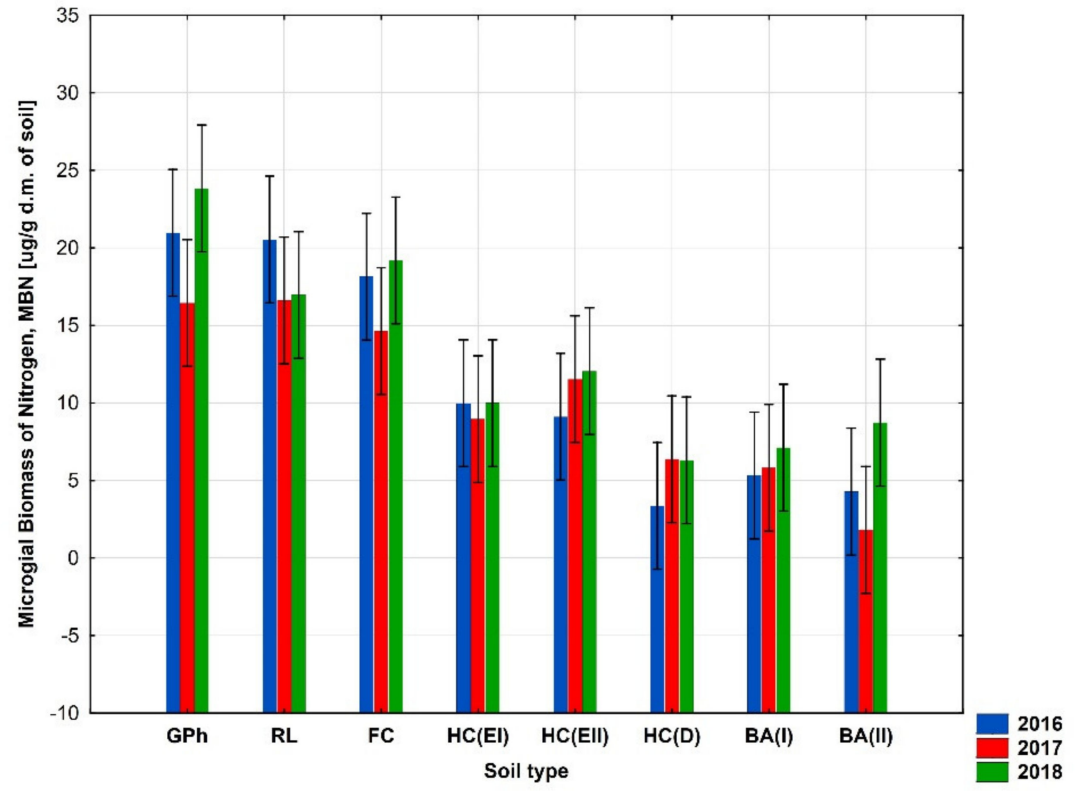

(B)

Figure 6. Microbial biomass analysis, ANOVA analysis (the soils were organised in this case from highest to lowest soil quality): (A) Microbial Biomass of Carbon (MBC); (B) Microbial Biomass of Nitrogen (MBN).

The total number of bacteria and fungi also varied depending on the type of soil and year (Figure 7). In the case of the total number of bacteria and total number of fungi, much greater variability was observed in years. 


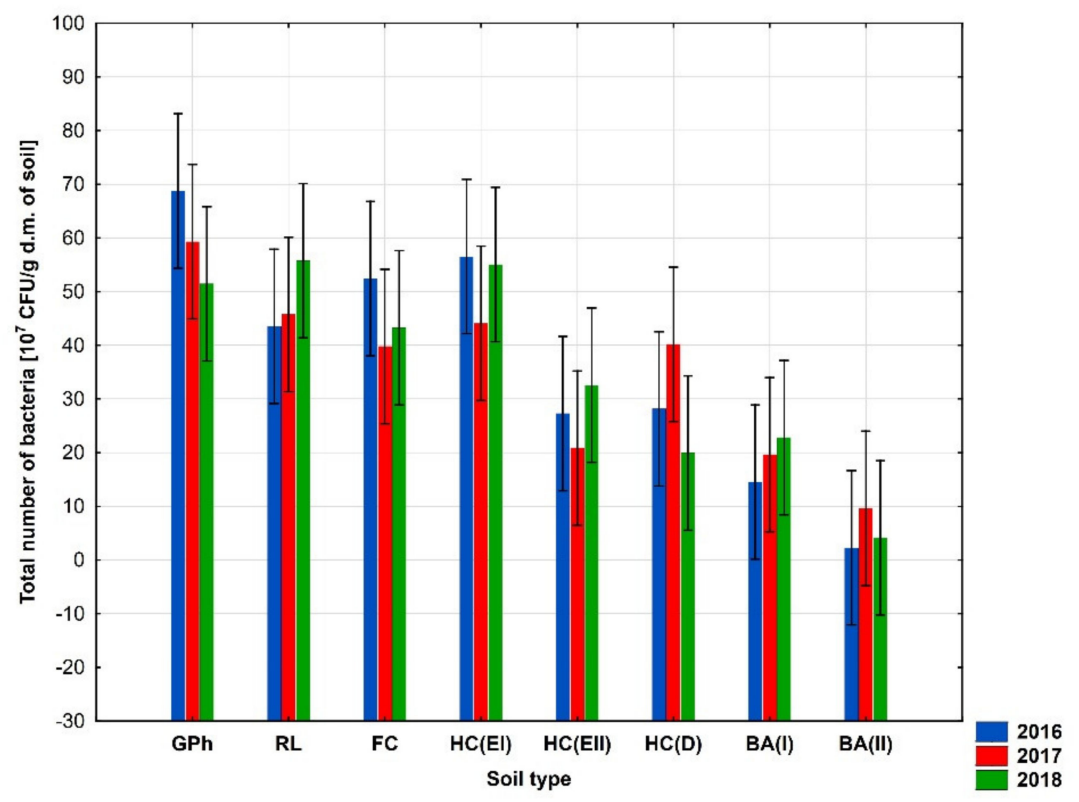

(A)

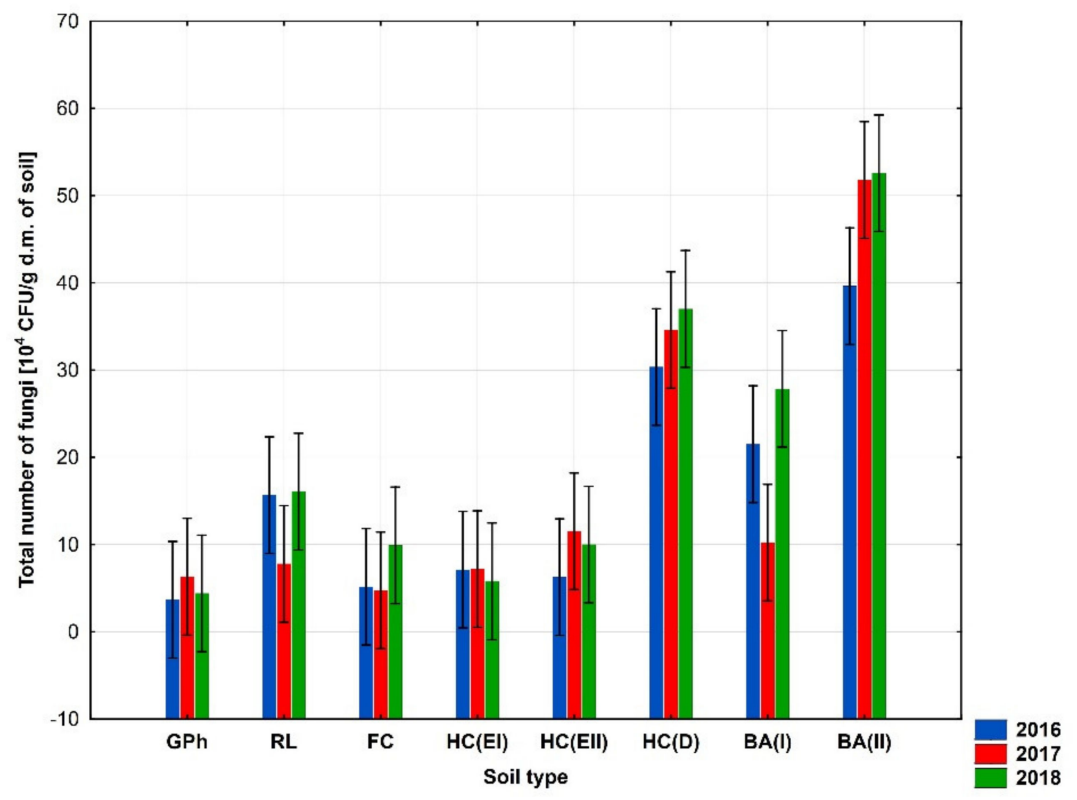

(B)

Figure 7. Total number of bacteria and fungi analysis, ANOVA analysis (the soils were organised in this case from highest to lowest soil quality): (A) Total number of bacteria; (B) Total number of fungi.

Table 9 presents a summary of means from 2016-2018 as changes in soil biological activity. Enzyme activity and $\mathrm{C}$ and $\mathrm{N}$ biomass as well as the total number of bacteria and fungi are discussed above. On the other hand, in the case of the total number of ammonification bacteria, the highest number of these bacteria was found in soil samples Rendzic Leptosol, Gleyic Phaeozem and Haplic Cambisol (Dystric), (Table 8). A higher total number of Azotobacter spp. was observed only in soil Rendzic Leptosol, Fluvic Cambisol and Gleyic Phaeozem (Table 9). The presence of Azotobacter bacteria depended on the $\mathrm{pH}$ of soil. Azotobacter spp. prefers neutral soils (pH 7.0-7.5). 
Table 9. Microbial diversity in different soil types (the soils were grouped according to the $S$ Index value from the lowest value to the highest). Treatment means separated by different letters are significantly different (Tukey's mean separation test, $p<0.05$ ); average for years 2016-2018 ( $n=9$ ).

\begin{tabular}{|c|c|c|c|c|c|c|c|c|c|}
\hline Soil Type & DHA & AlP & $\mathrm{AcP}$ & MBC & MBN & Bacteria & Fungi & Amo & Azo \\
\hline Brunic Arenosol (Dystric I) & $5.524^{\mathrm{d}}$ & $8.525^{\mathrm{d}}$ & $34.628^{b}$ & $53.867^{c}$ & $4.074^{\mathrm{c}}$ & $12.949^{c}$ & $16.906^{b}$ & $6.475^{b}$ & $0.000^{c}$ \\
\hline Brunic Arenosol (Dystric II) & $5.401^{d}$ & $8.648^{d}$ & $41.257^{\mathrm{b}}$ & $83.378^{b}$ & $7.476^{\mathrm{b}}$ & $0.352^{\mathrm{d}}$ & $21.795^{\mathrm{a}}$ & $2.109^{c}$ & $0.000^{\mathrm{a}}$ \\
\hline Fluvic Cambisol & $70.478^{b}$ & $77.268^{b}$ & $30.418^{b}$ & $59.378^{c}$ & $17.418^{a}$ & $49.772^{a}$ & $6.079^{c}$ & $7.219^{b}$ & $199.467^{\mathrm{a}}$ \\
\hline Rendzic Leptosol & $93.348^{\mathrm{a}}$ & $90.357^{b}$ & $37.644^{b}$ & $150.222^{\mathrm{a}}$ & $19.268^{a}$ & $39.089^{b}$ & $11.114^{\mathrm{b}}$ & $11.497^{\mathrm{a}}$ & $173.985^{\mathrm{a}}$ \\
\hline Haplic Cambisol (Dystric) & $24.968^{c}$ & $17.038^{\mathrm{c}}$ & $57.903^{a}$ & $67.556^{\mathrm{b}}$ & $5.150^{\mathrm{c}}$ & $26.862^{b}$ & $27.936^{a}$ & $12.177^{\mathrm{a}}$ & $0.000^{\mathrm{c}}$ \\
\hline Haplic Cambisol (Eutric II) & $40.641^{\mathrm{c}}$ & $28.975^{c}$ & $54.069^{\mathrm{a}}$ & $45.689^{c}$ & $7.990^{b}$ & $20.862^{b}$ & $8.196^{c}$ & $7.078^{b}$ & $1.863^{\mathrm{b}}$ \\
\hline Haplic Cambisol (Eutric I) & $44.232^{c}$ & $29.256^{c}$ & $56.882^{a}$ & $39.911^{c}$ & $8.953^{b}$ & $54.072^{\mathrm{a}}$ & $7.184^{\mathrm{c}}$ & $6.806^{\mathrm{a}}$ & $1.513^{b}$ \\
\hline Gleyic Phaeozem & $115.036^{\mathrm{a}}$ & $128.880^{\mathrm{a}}$ & $43.044^{\mathrm{a}}$ & $138.578^{a}$ & $20.185^{a}$ & $65.961^{\mathrm{a}}$ & $8.294^{c}$ & $9.874^{b}$ & $187.218^{a}$ \\
\hline
\end{tabular}

Explanation: DHA—dehydrogenases ( $\mu \mathrm{g}$ formazan/g d.m. (dry matter) of soil/24 h); AlP—alkaline phosphatase ( $\mu \mathrm{g} p$-nitrophenol/g d.m. of soil/h); AcP—acid phosphatase ( $\mu \mathrm{g}$
p-nitrophenol/g d.m. of soil/h); MBC—-microbial biomass C ( $\mu \mathrm{g} / \mathrm{g} \mathrm{d.m.} \mathrm{of} \mathrm{soil);} \mathrm{MBN—-microbial} \mathrm{biomass} \mathrm{N} \mathrm{(} \mu \mathrm{g} / \mathrm{g}$ d.m. of soil); bacteria (10 $\mathrm{CFU}$ (colony-forming units)/g d.m. of soil);

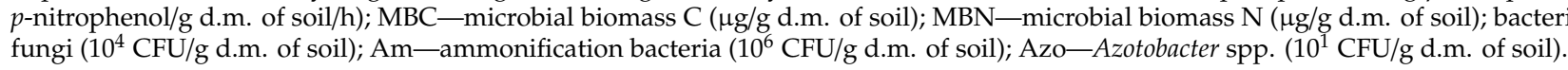


Based on the parameters of microbiological activity, soil types were grouped on two main groups. Based on Ward's cluster analysis, two main groups were distinguished (Figure 8). The first group included soil types with high biological activity: Gleyic Phaeozem, Fluvic Cambisol and Rendzic Leptosol, while the second group included soils with lower soil biological activity: Haplic Cambisol (Distric), Haplic Cambisol (Eutric II), Haplic Cambisol (Eutric I), Brunic Arenosol (Distric I) and Brunic Arenosol (Distric II). In addition, the first group distinguished two subgroups, the first containing Gleyic Phaeozem and the second Fluvic Cambisol and Rendzic Leptosol. In turn, in the second group, three subgroups were distinguished, the first containing Haplic Cambisol (Distric), the second Haplic Cambisol (Eutric II), Haplic Cambisol (Eutric I) and the third), Brunic Arenosol (Distric I) and Brunic Arenosol (Distric II), (Figure 8).

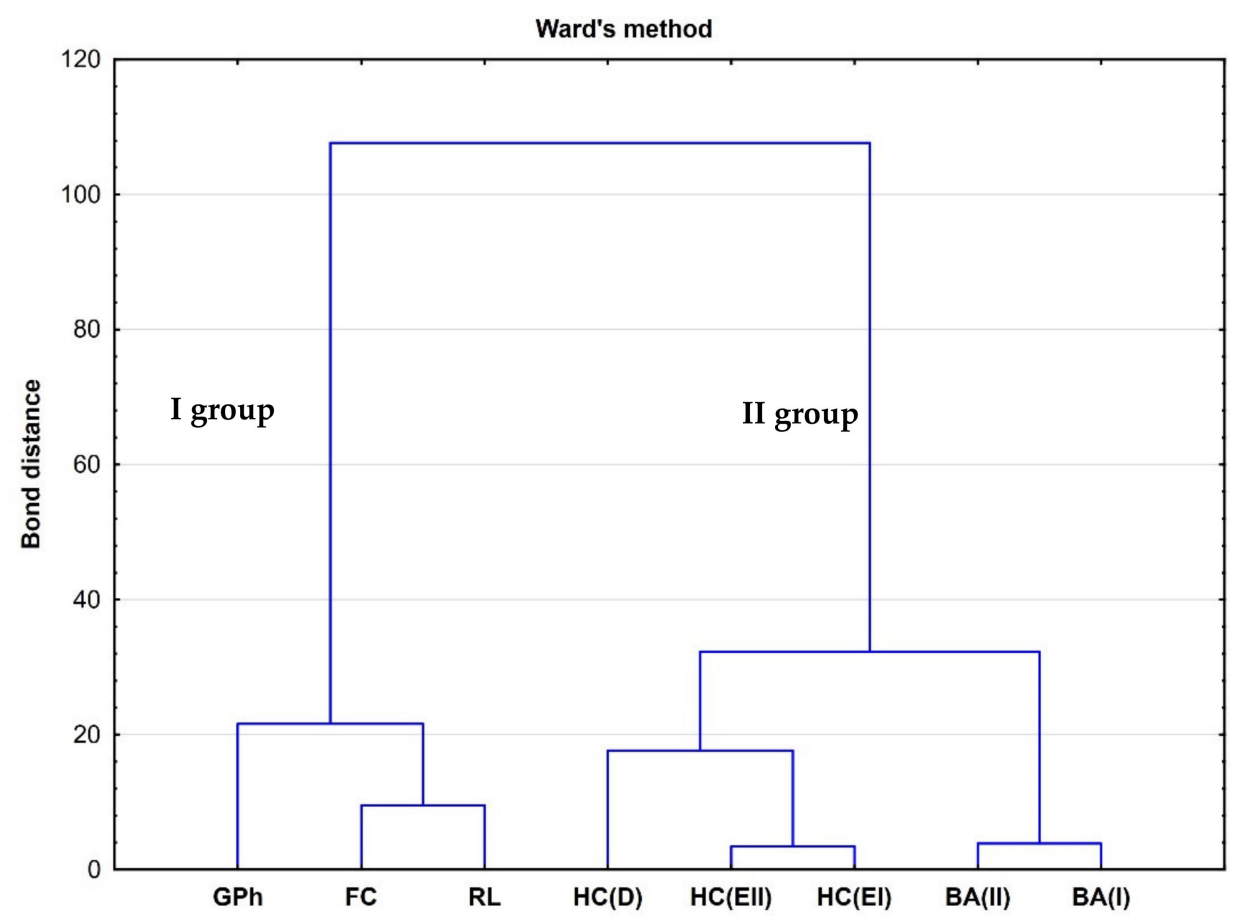

Figure 8. Dendrogram of the bond distances between of selected microbiological, chemical and biochemical parameters and GRSP content (see Table 9).

The Pearson's correlation coefficient of selected microbiological, chemical and biochemical parameters and GRSP content are presented in Table 10. Statistically significant correlations were found between the TG-GRSP content and the enzymatic activity of soils and the total number of bacteria as well as the content of carbon $\left(\mathrm{C}_{\mathrm{org}}\right)$ and nitrogen in the biomass of microorganisms (Table 10). The S-Index value was closely correlated with the glomalin content (T-GRSP and EE-GRSP), dehydrogenase activity (DHA) and the total number of bacteria. The glomalin content was additionally correlated with the number of AMF spores with a diameter of $150 \mu \mathrm{m}$.

The correlation coefficients for selected parameters of soil biological activity and GRSP content between the two principal components PC1 and PC2 in the PCA are presented in Table 9. The principal components of the PCA analysis showed strong correlations between the parameters of soil types and microbial indicators. Selected indicators of soil microbial diversity explained $71.73 \%$ of biological variability in soils (Table 11). 
Table 10. Pearson's correlation coefficient $(p \leq 0.05)$ of selected microbiological, chemical and biochemical parameters and glomalin content.

\begin{tabular}{|c|c|c|c|c|c|c|c|c|c|c|c|c|c|c|c|c|c|c|}
\hline & \multirow[t]{2}{*}{ AlP } & \multirow[t]{2}{*}{ AcP } & \multirow[t]{2}{*}{ МBC } & \multirow[t]{2}{*}{ MBN } & \multirow[t]{2}{*}{ Bacteria } & \multirow[t]{2}{*}{ Fungi } & \multirow[t]{2}{*}{ Amo } & \multirow[t]{2}{*}{ Azo } & \multirow[t]{2}{*}{$\mathbf{N}[\%]$} & \multirow[t]{2}{*}{$\mathrm{C}[\%]$} & \multirow[t]{2}{*}{ RDC/TG } & \multirow[t]{2}{*}{ S-Index } & \multirow[t]{2}{*}{ T-GRSP } & \multirow[t]{2}{*}{ EE-GRSP } & \multicolumn{3}{|c|}{$\begin{array}{c}\text { Total Number of the Spores } \\
(\mu \mathrm{m})\end{array}$} & \multirow{2}{*}{$\begin{array}{c}\text { All } \\
\text { AMF } \\
\text { Spore }\end{array}$} \\
\hline & & & & & & & & & & & & & & & 150 & 100 & 50 & \\
\hline DHA & $0.979 *$ & -0.200 & 0.703 & $0.945^{*}$ & $0.836^{*}$ & -0.622 & 0.551 & $0.878^{*}$ & $0.882 *$ & $0.934^{*}$ & 0.734 * & $0.725 *$ & $0.897^{*}$ & 0.679 & 0.382 & 0.091 & 0.225 & 0.224 \\
\hline AlP & & -0.343 & $0.744^{*}$ & $0.960^{*}$ & $0.789^{*}$ & -0.573 & 0.475 & $0.925 *$ & $0.899 *$ & $0.962 *$ & 0.699 & 0.625 & $0.876^{*}$ & 0.539 & 0.361 & 0.044 & 0.112 & 0.133 \\
\hline $\mathrm{AcP}$ & -0.343 & & -0.328 & -0.440 & 0.025 & 0.225 & 0.213 & -0.592 & -0.044 & -0.222 & -0.450 & 0.496 & 0.049 & 0.482 & 0.192 & 0.303 & 0.668 & 0.554 \\
\hline MBC & 0.744 * & -0.328 & & $0.731^{*}$ & 0.315 & -0.053 & 0.440 & 0.669 & 0.622 & $0.796^{*}$ & 0.311 & 0.287 & 0.497 & 0.226 & -0.051 & -0.319 & -0.034 & -0.162 \\
\hline MBN & 0.960 * & -0.440 & 0.731 * & & $0.723 *$ & -0.611 & 0.361 & 0.959 * & $0.749 *$ & 0.861 * & 0.822 * & 0.512 & 0.771 * & 0.475 & 0.286 & 0.026 & 0.131 & 0.127 \\
\hline Bacteria & 0.789 * & 0.025 & 0.315 & $0.723 *$ & & -0.647 & 0.502 & 0.673 & 0.799 * & $0.745^{*}$ & 0.694 & $0.785^{*}$ & $0.795^{*}$ & 0.661 & 0.275 & 0.100 & 0.351 & 0.289 \\
\hline Fungi & -0.573 & 0.225 & -0.053 & -0.611 & -0.647 & & 0.035 & -0.530 & -0.443 & -0.422 & -0.775 * & -0.417 & -0.593 & -0.599 & -0.430 & -0.095 & 0.036 & -0.075 \\
\hline Amo & 0.475 & 0.213 & 0.440 & 0.361 & 0.502 & 0.035 & & 0.391 & 0.523 & 0.539 & 0.229 & 0.588 & 0.459 & 0.475 & 0.082 & 0.186 & 0.304 & 0.272 \\
\hline Azo & 0.925 * & -0.592 & 0.669 & 0.959 * & 0.673 & -0.530 & 0.391 & & 0.695 & $0.813 *$ & 0.817 * & 0.379 & 0.686 & 0.295 & 0.245 & 0.070 & 0.015 & 0.071 \\
\hline $\mathrm{N}[\%]$ & $0.899 *$ & -0.044 & 0.622 & $0.749 *$ & $0.799 *$ & -0.443 & 0.523 & 0.695 & & 0.960 * & 0.394 & $0.775 *$ & $0.937^{*}$ & 0.617 & 0.463 & 0.102 & 0.189 & 0.217 \\
\hline $\mathrm{C}[\%]$ & 0.962 & -0.222 & $0.796^{*}$ & 0.861 * & $0.745^{*}$ & -0.422 & 0.539 & $0.813^{*}$ & $0.960 *$ & & 0.493 & 0.659 & $0.879 *$ & 0.533 & 0.328 & -0.029 & 0.094 & 0.087 \\
\hline RDC/TG & 0.699 & -0.450 & 0.311 & $0.822 *$ & 0.694 & -0.775 * & 0.229 & $0.817^{*}$ & 0.394 & 0.493 & & 0.331 & 0.495 & 0.400 & 0.145 & 0.063 & 0.095 & 0.103 \\
\hline S-Index & 0.625 & 0.496 & 0.287 & 0.512 & $0.785^{*}$ & -0.417 & 0.588 & 0.379 & 0.775 * & 0.659 & 0.331 & & $0.867 *$ & $0.905^{*}$ & 0.588 & 0.424 & 0.682 & 0.666 \\
\hline T-GRSP & $0.876^{*}$ & 0.049 & 0.497 & $0.771 *$ & $0.795 *$ & -0.593 & 0.459 & 0.686 & 0.937 * & 0.879 * & 0.495 & $0.867 *$ & & $0.784 *$ & $0.790 *$ & 0.353 & 0.360 & 0.656 \\
\hline EE-GRSP & 0.539 & 0.482 & 0.226 & 0.475 & 0.661 & -0.599 & 0.475 & 0.295 & 0.617 & 0.533 & 0.400 & $0.905 *$ & 0.784 * & & 0.600 & 0.365 & 0.546 & 0.560 \\
\hline $150 \mu \mathrm{m}$ & 0.361 & 0.192 & -0.051 & 0.286 & 0.275 & -0.430 & 0.082 & 0.245 & 0.463 & 0.328 & 0.145 & 0.588 & $0.790 *$ & 0.600 & & $0.809 *$ & 0.374 & 0.698 \\
\hline $100 \mu \mathrm{m}$ & 0.044 & 0.303 & -0.319 & 0.026 & 0.100 & -0.095 & 0.186 & 0.070 & 0.102 & -0.029 & 0.063 & 0.424 & 0.353 & 0.365 & 0.809 * & & 0.582 & 0.878 \\
\hline $50 \mu \mathrm{m}$ & 0.112 & 0.668 & -0.034 & 0.131 & 0.351 & 0.036 & 0.304 & 0.015 & 0.189 & 0.094 & 0.095 & 0.682 & 0.360 & 0.546 & 0.374 & 0.582 & & $0.895^{*}$ \\
\hline All spores & 0.133 & 0.554 & -0.162 & 0.127 & 0.289 & -0.075 & 0.272 & 0.071 & 0.217 & 0.087 & 0.103 & 0.666 & 0.656 & 0.560 & 0.698 & 0.878 * & 0.895 * & \\
\hline
\end{tabular}

* Indicates statistically significant $(p \leq 0.05)$; average of 2016-2018 ( $n=9) \mathrm{C}_{\mathrm{org}}$-organic carbon content ( $\mathrm{g} / \mathrm{kg}$ of soil); N (g/kg of soil); see Table 9. 
Table 11. Results of principal component analysis.

\begin{tabular}{ccc}
\hline Variable & PC1 (48.35\%) & PC2 (23.38\%) \\
\hline DHA & -0.974 & 0.164 \\
AlP & -0.931 & 0.243 \\
AcP & 0.010 & -0.783 \\
MBC & -0.601 & 0.149 \\
MBN & -0.863 & 0.405 \\
Bacteria & -0.886 & -0.165 \\
Fungi & 0.578 & -0.383 \\
Amo & -0.634 & -0.340 \\
Azo & -0.791 & 0.487 \\
N [\%] & -0.908 & -0.098 \\
C [\%] & -0.907 & 0.051 \\
S-Index & -0.851 & -0.366 \\
RDC/TC & 0.827 & -0.160 \\
T-GRSP & -0.938 & 0.032 \\
EE-GRSP & -0.768 & -0.201 \\
Amines and amides & -0.197 & -0.873 \\
Carboxylic and acetic acids & -0.218 & -0.893 \\
Carbohydrates & -0.214 & -0.596 \\
Amino acids & 0.719 & -0.392 \\
Polymers & -0.393 & -0.513 \\
AWCD & -0.024 & -0.889 \\
Shannon index & -0.477 & -0.624
\end{tabular}

Correlation coefficients for principal component (PC) factors; average for years 2016-2018 $(n=9)$. For abbreviations, see Table 9.

The bi-plot PCA of selected microbiological and biochemical parameters, glomalin content, biodiversity indices and Biolog EcoPlate data from soil samples incubated for $120 \mathrm{~h}$ was presented in Figure 9. The Gleyic Phaeozem, Fluvic Cambisol and Rendzic Leptosol were characterized by high biological activity, for which there were strong correlations with such parameters as DHA, MBC, MBN, S-Index and total bacteria number (Figure 9). The Haplic Cambisol (Eutric I), Haplic Cambisol (Eutric II) and Haplic Cambisol (Distric) were characterized by biological activity and there were strong correlations with total number of fungi and acid phosphatase. The Brunic Arenosol (Distric I) and Brunic Arenosol (Distric II) were characterized by very low biological activity of soil (Figure 9).

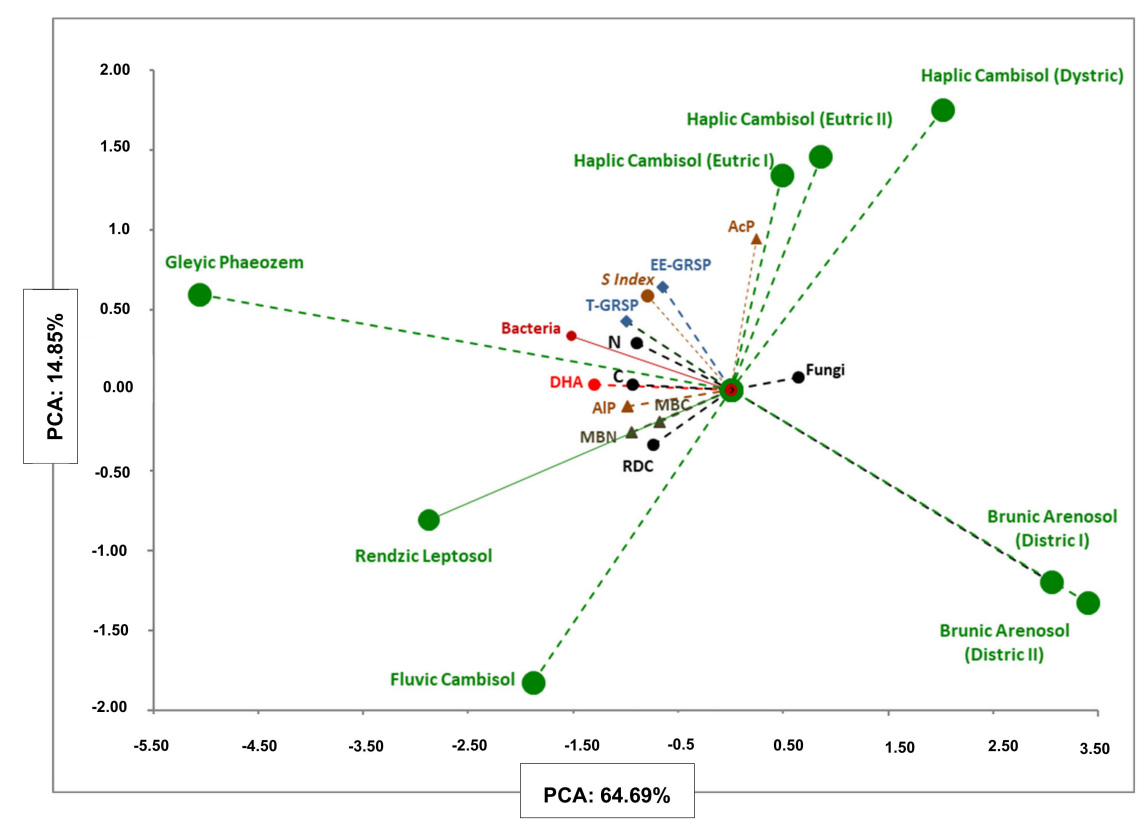

Figure 9. Principal component analysis of microbial parameters, biodiversity indices and Biolog EcoPlate data from soil samples incubated for $120 \mathrm{~h}$. See Table 11. 


\section{Discussion}

Investigations carried out in different countries have shown that GRSP is commonly recorded in soils $[7,8]$. It has been detected in agricultural soils, forest and meadow soils, and agricultural wasteland [13]. The highest concentration of GRSP was recorded in tropical forest soils (over $100 \mathrm{mg} / \mathrm{g}$ soil), whereas desert soils were characterized by the lowest glomalin concentrations (below $0.5 \mathrm{mg} / \mathrm{g}$ soil) [36,37]. In Poland, there have been no studies on the content of this important fraction of OM in different types of soils so far. Therefore, the aim of the study was to evaluate the changes in glomalin-related soil proteins (GRSP) content, microbial diversity and soil physical quality depending on the type of soil measures of soil improvement. Thanks to this, it will be possible to better understand how some microbiological and physicochemical properties affect the physical quality of soils, defined by the $\mathrm{S}$ index.

The highest T-GRSP and EE-GRSP content and higher microbial diversity were found in Gleyic Phaeozem and Rendzic Leptosol. The soils characterized by a low T-GRSP content were Brunic Arenosol (Dystric II). Soils with the lowest T-GRSP and EE-GRSP content were also characterized by the lowest soil stability measured as the proportion between TC content and RDC content. The glomalin related soil proteins content (T-GRSP and EE-GRSP) depended on the type of soil and correlated with S-Index. According to the $S$ index, soils with very poor and poor physical quality were characterized by the lowest content of T-GRSP, as well as with a low content of organic matter, very acidic reaction and sandy. In turn, soils characterized by the highest T-GRSP content belonged to the group of very good and good soil physical quality. Soils with a high T-GRSP content were more stable because the clay contained in them is not easily dispersible. This is all the more important because all the tested soil types are used in Poland for agriculture [3,4]. This indicates the need to care for the quality of the soil, in particular by maintaining or increasing the content of organic matter and maintaining the optimal soil $\mathrm{pH}$ for crops. Hence increas the soil quality and health will be crucial for improving plant growth and yield.

Small-scale environmental experiments are often linked with some concerns. One of them is that if microplots are located close to each other, they will eventually mix and unify the composition of the soil microbiota. These results demonstrate, however, that even if the effect occurred in the last 130 years, each soil retains its individuality in terms of microbiological composition. It also suggests that this negative effect may be only superficial, and a depth of $0-15 \mathrm{~cm}$ seems to be more or less resistant to such fluctuations. Soils from the original locations for experiment were placed in micro plots while maintaining the natural system of soil horizons and have undergone over 130 years of unchanged cereal production.

GRSP plays a significant role mainly in the formation of the soil aggregate stability, as it facilitates adhesion of mineral particles [14,38]. This protein covers the surface of soil particles, creating a characteristic, protective coating. Hence, due to the production of glomalin, AMF have aroused growing interest as a potential factor supporting plant growth and health and improving the soil structure [15]. Increasing soil inoculation by AMF can have an important impact on plant yield and soil health.

The role of AMF in soil aggregation and, hence, in enhanced water infiltration, protection of OM from decomposition, and enhanced soil resistance to erosion seems equally important or perhaps even more important than their role in nutrient uptake by plants. Therefore, control of the growth of mycorrhizal fungi and glomalin production may be useful for monitoring desertification and degradation of soil. Unfavourable conditions for the growth of endomycorrhizal fungi, i.e., soil contamination, climatic change or cultivation techniques, may be the reason for increased glomalin production aimed at protection of the mycelium [38].

Similarly, the physicochemical properties of soils may have a significant impact on the glomalin content in soil [13]. Soil microorganisms are the most important and at the same time the most diverse group of organisms that are part of the Earth's biosphere, creating multi-species communities and a network of relationships between individual physiological groups $[39,40]$. Therefore, the processes of 
soil formation and soil degradation carried out by communities of microorganisms should be seen as the sum of functions for which microbial communities are responsible, and not only individual species. Studies on the activity of microorganisms in communities are necessary to learn about the ecology of microorganisms in biocenoses and should be analysed in relation to existing environmental conditions and time [40].

In the paper by Czaban et al. [8], (research conducted on the same plots) the authors showed that soil microorganisms differing in their water requirements are associated with different soil particulars. The total number of bacteria is closely related to small particles and small pores usually filled with water, but non-xerophilic fungi are associated with medium particles and medium pores which are usually the region of near the air-water interface. Moreover, the number of colony forming units (CFU) of xerotolerant/xerophilic fungi and particularly formulated indices of xerotolerance of soil fungal communities (in contrast to CFU of bacteria) are negatively correlated with water content, soil OM content, soil $\mathrm{pH}$ and an index of soil quality [5]. Our results also show that the microbiological activity of soils and the GRSP content (T-GRSP and EE-GRSP) are closely related to the physical quality of soils and the S-Index. A strong correlation between S-Index and T-GRSP was demonstrated (Pearson's correlation coefficient $=0.867$ ). In addition, a close relationship between TG-GRSP and organic carbon (Pearson's correlation coefficient $=0.879)$ and nitrogen content $($ Pearson's correlation coefficient $=0.937)$ was demonstrated. It is very important in the context of preserving the original physical properties of these soils. Siebielec et al. [20] by conducting research on the same field experiment, determined that for over 20 years, soils have maintained at a similar level parameters such as $\mathrm{pH}$, organic carbon content, the amount of bioavailable potassium, phosphorus or magnesium. Our research shows that soils of good physical quality are characterized by a high content of T-GRSP, EE-GRSP [41,42].

Also, a negative impact of RDC content on physical soil quality was presented by Gate et al. [43] and Dexter and Czyż [17]. Czyż and Dexter [21] showed that clay dispersion, measured by the turbidity of the suspension, is a sensitive indicator of soil stability, which is important for protecting the soil environment. Basically, the soil is of poor physical quality when it shows low resistance to degradation caused by a high content of RDC. Which may be the reason for the low water infiltration rate, increased surface runoff, poor coherence, low aeration and root density as well as mechanization difficulties $[16,44,45]$.

In this study a significant number of AMF spores were found in soils. AMF spores may remain after harvesting plants from the previous year. And despite the fact that soil samples were taken before sowing (the plants were not yet in the field), so AMF spores were found in the soil. In our previous paper on the evaluation of the structural diversity of fungi on the same plots, only a small presence of AMF was found ( $<1 \%$, using next generation sequencing (NGS) [11]. Our results shows that the number of AMF spores was from 2.85 to 15.32 per $1 \mathrm{~g}$ of soil, i.e., $100 \mathrm{~g}$ is $\sim 300$ to 500 pieces of AMF spores. Calculated for the amount used for DNA isolation (about $350 \mathrm{mg}$ of soil), in our previous paper with NGS, there are about 2 spores in the soil sample. Therefore, with such a small amount taken for testing in the sequencing of the ITS variable region for fungi in the NGS method, it could happen that this material has not been amplified. Similar results in AMF spores were obtained by authors of other papers [46-48]. Therefore, the results obtained by us are all the more valuable because both a modern research method (NGS in paper Grzadziel and Gałazka [11]) and traditional methods of counting AMF spores were used in the present study. These methods will complement each other very well.

The amount of OM in soils is the basic indicator of soil quality assessment in terms of their physicochemical properties, such as sorption and buffer abilities, as well as their biological transformation processes, important from the point of view of habitat functioning and referred to as biological activity. A high organic carbon content in soils is a factor stabilizing their structure, reducing susceptibility to compaction and degradation due to water and wind erosion, and positively affecting the physical quality of soils [1]. Our results also confirm this, indicating that the highest physical quality of soils was characterized by the soil with the highest organic matter content (Gleyic Phaeozem). 
This is all the more important as organic matter is a fundamental indicator of soil health. In addition, soils rich in organic matter are also of great importance in carbon sequestration [44,45].

The European Parliament resolution (EP Resolution 2007) lists among the main threats to the proper functioning of soils a decrease in the content of $\mathrm{OM}$, because its loss can cause many adverse phenomena associated with the disturbance of chemical, physical and biological processes that directly affect the quality of soil and its fertility [46-50]. Among the 8 types of analyzed soils, Gleyic Phaeozem, as a soil rich in organic matter, is the most sensitive to. Their share in the area of mineral soils in Poland does not exceed 2\% [3]. That is why it is so important to properly manage these soils so as not to lose organic matter in them. The preservation of soil organic matter is important not only for maintaining the productive functions of soils, but also for the role of soils in the sequestration (binding) of carbon dioxide from the atmosphere, contributing to the reduction of the greenhouse effect [4]. The soil with the highest agricultural productivity in Poland constitutes only about $26 \%$ of all arable land, which covers about $60 \%$ of the country's area. This group also includes Gleyic Phaeozems, which in Poland are predominantly over $90 \%$ agricultural land. Haplic Cambisols-developed from loess, some Fluvisols and Rendzic Leptosols are also highly productive. Hence the greatest care to maintain these soils of the best quality. These are the most productive soils, where the highest yields are obtained. Moreover, these are soils characterized by high water retention and high resistance to chemical degradation. For these reasons, in Poland, first of all, soils with the highest productivity should be protected against non-agricultural use and against degradation [3]. The remaining soil types are low productivity soils and account for more than $70 \%$ of the agricultural land area. The majority of them are sandy soils with low water retention and low organic carbon content [3,4].

Due to the diversity and activity of soil microorganisms, different types of soil aggregates are formed, in which the cells are bacterial and fungal hyphae, as well as polysaccharides synthesized by microorganisms, ensuring stability and giving appropriate structure to the soil [51-53]. The benefits of improving soil structure directly related to maintaining biodiversity, especially in agricultural environments, include: reduced risk of erosion, better root penetration and better access to soil moisture and nutrients, easier germination due to reduced surface crusting, and greater infiltration, retention and availability water due to improved porosity.

In the paper by Sarapatka et al. [53], the authors showed the importance of glomalin in soil degradation. The authors studied the sensitivity and changes of glomalin in the soil environment as a result of soil degradation, how it correlates with other soil characteristics, and how useful it is for indicating changes in soil properties. Statistically significant differences were recorded between erosional and depositional sites, the latter showing higher concentrations of both glomalin and characteristics relating to soil $\mathrm{OM}$ and content of nutrients.

Therefore, it is extremely important to search for and develop effective low-cost environmentally friendly solutions and techniques that can be effective tools for improving the quality of the soil environment, in particular in light of increasing the OM content in soil sustainable agriculture [54]. Undoubtedly, increased presence of glomalin-producing mycorrhizal fungi in the soil can be one of such solutions. Furthermore, investigations of the impact of soil type on the microbiological quality of the soil environment indicated by selected parameters of soil biological quality allowed a profound analysis of not only quantitative but also qualitative changes occurring in soil OM and microbial communities. They also allowed assessment of these relationships in a broader aspect of soil productivity protection. The obtained research results may be useful in planning the soil sustainable management because they indicate the role of microbiological properties on the physical quality of soils, which is one of the elements determining soil health. However, study by Lobry de Bruyn and Andrews [55], revealed there may be some problems when it comes to using soil health research as a decision-making tool, and all of these guide best practice. To make and maintain soil sustainable management, farmers want to be confident that the benefits to their soil are real. Soil assessment and monitoring can benefit us all stakeholders, including farmers if undertaken with clear guidelines and within supportive structures. 
Undoubtedly, increased presence of glomalin-producing mycorrhizal fungi in the soil can be one of such solutions. Furthermore, investigations of the impact of soil type on the microbiological quality of the soil environment indicated by selected parameters of soil biological quality allowed a profound analysis of not only quantitative but also qualitative changes occurring in soil OM and microbial communities. They also allowed assessment of these relationships in a broader aspect of soil productivity protection.

\section{Conclusions}

1. The content of glomalin related soil proteins depended not only on the soil type but also on the biological and physical activities and correlated with S-Index and was the important biotic determinant of soil quality.

2. Significant correlations were found between the total carbon content $(\% \mathrm{C})$ and the concentration of T-GRSP and EE-GRSP. Soils characterized by highest GRSP content belonged to the group of very good and good SPQ characterized also by high biological activity.

3. Soil biological activity depended strictly on the type of soil and remained stable over the years examined. The Gleyic Phaeozem, Fluvic Cambisol and Rendzic Leptosol were characterized by high biological activity, for which there were strong correlations with such parameters as DHA, MBC, MBN, S-Index and total bacteria number. The Haplic Cambisol (Eutric I), Haplic Cambisol (Eutric II) and Haplic Cambisol (Distric) were characterized by moderate biological activity and there were strong correlations with total number of fungi and acid phosphatase. The Brunic Arenosol (Distric I) and Brunic Arenosol (Distric II) were characterized by very low biological activity of soil.

4. This research indicates that a specific edaphone of soil microorganisms may be of great importance when assessing potential soil resistance to degradation and improving quality and health. Our research indicates a significant role of soil organic carbon content on soil quality, which may also have important implications and connections to carbon sequestration, preventing the negative effects of climate change and improving soil health and biodiversity of soil microorganisms.

Author Contributions: Conceptualization, A.G.; methodology, A.G., J.N., J.G. and K.G.; software, A.G. and J.G.; investigation, A.G. and J.N.; writing-original draft preparation, A.G., J.N. and J.G.; visualization, A.G., J.N. and J.G.; supervision, A.G.; funding acquisition, A.G. All authors have read and agreed to the published version of the manuscript.

Funding: The research was conducted within the statutory activity of IUNG-PIB (1.20) and the frames of Task 1.2 "Agricultural soils evaluation taking into account proper functioning of soil ecosystems and indication of actions preventing degradation processes" and 1.4. "Evaluation and formation of biodiversity of soil and microbial activity of soil with regard to habitat conditions and management system", Multi-Annual Programme IUNG-PIB (2016-2020).

Acknowledgments: The authors thank technical staff Jarosław Ciepiel, Olga Ciotucha and Andrzej Księżniak for their help in laboratory experiments. The authors thank the Department of Cereal Crop Production for providing microplots for research.

Conflicts of Interest: The authors declare no conflict of interest.

\section{References}

1. Ukalska-Jaruga, A.; Klimkowicz-Pawlas, A.; Smreczak, B. Characterization of organic matter fractions in the top layer of soils under different land uses in Central-Eastern Europe. Soil Use Manag. 2019, 35, 595-606. [CrossRef]

2. Kibblewhite, M.G.; Ritz, K.; Swift, M.J. Soil health in agricultural systems. Philos. Trans. R. Soc. B 2008, 363, 685-701. [CrossRef] [PubMed]

3. Skłodowski, P.; Bielska, A. Properties and fertility of soils in Poland-a basis for the formation of agro-environmental relations. Water Environ. Rural Areas 2009, 9, 203-2014. (In Polish)

4. Krasowicz, S.; Oleszek, W.; Horabik, J.; Dębicki, R.; Jankowiak, J.; Stuczyński, T.; Jadczyszyn, J. Rational managenent of the soil environment in Poland. Pol. J. Agron. 2011, 7, 43-58. (In Polish) 
5. Grzadziel, J. Structural and Functional Diversity of Microorganisms in Selected Soil Types Characteristic of Poland. Ph.D. Thesis, Insitute of Soil Science and Plant Cultivation, State Research Institute, Puławy, Poland, 23 June 2020.

6. Czyż, E.A.; Dexter, A.R.; Niedźwiecki, J. Soil water retention of long-term permanent plot experiments. Soil Sci. Ann. 2003, 4, 27-37. (In Polish)

7. Gałązka, A.; Gawryjołek, K.; Grządziel, J.; Księżak, A. Effect of different agricultural management practices on soil biological parameters including glomalin fraction. Plant Soil Environ. 2017, 63, 300-306.

8. Czaban, J.; Wróblewska, B.; Niedźwiecki, J.; Sułek, A. Relationships between numbers of microbial communities in Polish agricultural soils and properties of these soils, paying special attention to xerophilic/xerotolerant fungi. Pol. J. Environ. Stud. 2010, 19, 1171-1183.

9. Grządziel, J.; Furtak, K.; Gałazka, A. Community-level physiological profiles of microorganisms from different types of soil that are characteristic to Poland-A long-term microplot experiment. Sustainability 2019, 11, 56. [CrossRef]

10. Grządziel, J.; Gałązka, A. Microplot long-term experiment reveals strong soil type influence on bacteria composition and its functional diversity. Appl. Soil Ecol. 2018, 124, 117-123. [CrossRef]

11. Grzadziel, J.; Gałązka, A. Fungal biodiversity of the most common types of Polish soil in a long-term microplot experiment. Front. Microbiol. 2019, 10, 6. [CrossRef]

12. Jamiołkowska, A.; Księżniak, A.; Hetman, B.; Kopacki, M.; Skwaryło-Bednarz, B.; Gałązka, A.; Thanoon, A.H. Interaction of arbuscular mycorrhizal fungi with plants and soil microflora. Acta Sci. Pol. Hortorum Cultus 2017, 16, 89-95. [CrossRef]

13. Gałązka, A.; Gawryjołek, K. Glomalin-soil glicoprotein produced by arbuscular mycorhizal fungus. Postępy Mikrobiol. 2015, 54, 331-343.

14. Gillespie, A.W.; Farrell, R.E.; Walley, F.L.; Ross, A.R.S.; Leinweber, P.; Eckhardt, K.U.; Tom, Z.; Regier, T.Z.; Blyth, R.I.R. Glomalin-related soil protein contains non-mycorrhizal-related heat-stable proteins, lipids and humic materials. Soil Biol. Biochem. 2011, 43, 766-777. [CrossRef]

15. Wang, W.; Zhong, Z.; Wang, Q.; Wang, H.; Fu, Y.; He, X. Glomalin contributed more to carbon, nutrients in deeper soils, and differently associated with climates and soil properties in vertical profiles. Sci. Rep. 2017, 7, 13003. [CrossRef]

16. Dexter, A.R. Soil physical quality: Part I. Theory, effects of soil texture, density, and organic matter, and effects on root growth. Geoderma 2004, 120, 201-214. [CrossRef]

17. Dexter, A.R.; Czyz, E.A. Applications of S-theory in the study of soil physical degradation and its consequences. Land Degrad. Dev. 2007, 18, 369-381. [CrossRef]

18. Gate, O.P.; Czyz, E.A.; Dexter, A.R. Soil physical quality, $S$, as a basis for relationships between some key physical properties of arable soils. Adv. Geoecology 2006, 38, 102-109.

19. Strzemski, M. The History of Polish Soil Science from the Dawn of Polish Literature to the Establishment of the Second Polish Republic; PWRiL: Warszawa, Poland, 1980. (In polish)

20. Siebielec, G.; Siebielec, S.; Podolska, G. Comparison of microbial and chemical characteristics of soil types after over 100 years of cereal production. Pol. J. Agron. 2015, 23, 88-100.

21. Czyż, E.; Dexter, A.R. Mechanical dispersion of clay from soil into water: Readily-dispersed and spontaneously-dispersed clay. Int. Agrophys. 2015, 29, 31-37. [CrossRef]

22. Genuchten, M.T.V. A closed-form equation for predicting the hydraulic conductivity of unsaturated soils. Soil Sci. Soc. Am. J. 1980, 44, 892-898. [CrossRef]

23. Martin, J.P. Use of acid, rose bengal and streptomycin in the plate method for estimating soil fungi. Soil Sci. 1950, 69, 215-232. [CrossRef]

24. Rodina, A. Microbiological Methods for the Study of Water; PWRiL: Warszawa, Poland, 1968. (In Polish)

25. Fenglerowa, W. Simple method for counting azotobacter in soil samples. Acta Microbiol. Pol. 1965, 14, 203-206.

26. Ghani, A.; Dexter, M.; Perrott, K.W. Hot-water extractable carbon in soils: A sensitive measurement for determining impacts of fertilization, grazing and cultivation. Soil Biol. Biochem. 2003, 35, 1231-1243. [CrossRef]

27. Determination of Dehydrogenase Activity in Soil Using 2,3,5 Triphenyltetrazolium Chloride (TTC); Polish Standard: Warsaw, Poland, 2011; PN-EN ISO 23753-1.

28. Tabatabai, M.A. Soil enzymes. In Methods of Soil Analysis, Part 2; Page, A.L., Miller, R.H., Keeney, D.R., Eds.; American Society of Agronomy and Soil Science Society of America: Madison, WI, USA, 1982. 
29. Wright, S.F.; Franke-Synder, M.; Morton, J.B.; Upadhyaya, A. Time course study and partial characterization of a protein on hyphae of arbuscular mycorrhizal fungi during active colonization of roots. Plant Soil 1996, 181, 193-203. [CrossRef]

30. Phillips, J.M.; Hayman, D.S. Improved procedures for clearing roots and staining parasitic and vesicular-arbuscular mycorrhizal fungi for rapid assessment of infection. Trans. Br. Mycol. Soc. 1970, 55, 158-161. [CrossRef]

31. Weisburg, W.G.; Barns, S.M.; Pelletier, D.A.; Lane, D.J. $16 \mathrm{~S}$ ribosomal DNA amplification for phylogenetic study. J. Bacteriol. 1991, 173, 697-703. [CrossRef]

32. Muyzer, G.; Waal, E.C.D.E.; Uitierlinden, A.G. Profiling of complex microbial populations by denaturing gradient gel electrophoresis analysis of polymerase chain reaction-amplified genes coding for 16S rRNA. Appl. Environ. Microbiol. 1993, 59, 695-700. [CrossRef]

33. Stach, J.E.M.; Maldonado, L.A.; Ward, A.C.; Goodfellow, M.; Bull, A.T. New primers for the class actinobacteria: Application to marine and terrestrial environments. Environ. Microbiol. 2003, 5, 828-841. [CrossRef]

34. Gałązka, A.; Gawryjołek, K.; Grządziel, J.; Frąc, M.; Księżak, J. Microbial community diversity and the interaction of soil under maize growth in different cultivation techniques. Plant Soil Environ. 2017, 63, 264-270. [CrossRef]

35. Chau, J.F.; Bagtzoglou, A.C.; Willig, M.R. The effect of soil texture on richness and diversity of bacterial communities. Environ. Forensics 2011, 12, 333-341. [CrossRef]

36. Nikolausz, M.; Sipos, R.; Révész, S.; Székely, A.; Márialigeti, K. Observation of bias associated with re-amplification of DNA isolated from denaturing gradient gels. FEMS Microbiol. Lett. 2005, 244, 385-390. [CrossRef] [PubMed]

37. Furtak, K.; Gawryjołek, K.; Gajda, A.; Gałazka, A. Effects of maize and winter wheat grown under different cultivation techniques on biological activity of soil. Plant Soil Environ. 2017, 63, 449-454.

38. Gałązka, A.; Gawryjołek, K.; Gajda, A.; Furtak, K.; Księżniak, A.; Jończyk, K. Assessment of the glomalins content in the soil under winter wheat in different crop production systems. Plant Soil Environ. 2018, 64, $32-37$.

39. Latour, X.; Philippot, L.; Corberand, T.; Lemanceau, P. The establishment of an introduced community of fluorescent pseudomonads in the soil and in the rhizosphere is affected by the soil type. FEMS Microbiol. Ecol. 1999, 30, 163-170. [CrossRef] [PubMed]

40. Schreiter, S.; Ding, G.-C.; Heuer, H.; Neumann, G.; Sandmann, M.; Grosch, R.; Kropf, S.; Smalla, K. Effect of the soil type on the microbiome in the rhizosphere of field-grown lettuce. Front. Microbiol. 2014, 5, 1-13. [CrossRef] [PubMed]

41. Sessitsch, A.; Weilharter, A.; Gerzabek, M.H.; Kirchmann, H.; Kandeler, E. Microbial population structures in soil particle size fractions of a long-term fertilizer field experiment. Appl. Environ. Microbiol. 2001, 67, 4215-4224. [CrossRef]

42. Lehman, R.M.; Cambardella, C.A.; Stott, D.E.; Acosta-Martinez, V.; Manter, D.K.; Buyer, J.S.; Maul, J.E.; Smith, J.L.; Collins, H.P.; Halvorson, J.J.; et al. Understanding and enhancing soil biological health: The solution for reversing soil degradation. Sustainability 2015, 7, 988-1027. [CrossRef]

43. Gaţe, O.P.; Czyż, E.A.; Dexter, A.R. Effects of readily-dispersible clay on soil quality and root growth. In Plant Growth in Relation to Soil Physical Conditions; Lipiec, J., Walczak, R., Józefaciuk, G., Eds.; Institute of Agrophysics, Polish Academy of Science: Lublin, Poland, 2004.

44. Lal, R. Soil health and carbon management. Food Energy Secur. 2016, 5, 212-222. [CrossRef]

45. Norris, C.E.; Bean, G.M.; Cappellazzi, S.B.; Cope, M.; Greub, K.L.H.; Liptzin, D.; Rieke, E.L.; Tracy, P.W.; Morgan, C.L.S.; Honeycutt, C.W. Introducing the North American project to evaluate soil health. Meas. Agron. J. 2020, 1-21. [CrossRef]

46. He, F.; Chen, H.; Tang, M. Arbuscular mycorrhizal fungal communities are influenced by host tree species on the loess plateau, northwest China. Forests 2019, 10, 930. [CrossRef]

47. Verzeaux, J.; Nivelle, E.; Roger, D.; Hirel, B.; Dubois, F.; Tetu, T. Spore density of arbuscular mycorrhizal fungi is fostered by six years of a No-Till system and is correlated with environmental parameters in a silty loam soil. Agronomy 2017, 7, 38. [CrossRef]

48. Melo, C.D.; Walker, C.; Krüger, C.; Borges, P.A.V.; Luna, S.; Mendonça, D.; Fonseca, H.M.A.C.; Machado, A.C. Environmental factors driving arbuscular mycorrhizal fungal communities associated with endemic woody plant Picconia azorica on native forest of Azores. Ann. Microbiol. 2019, 69, 1309-1327. [CrossRef] 
49. Onet, A.; Dinca, P.; Laslo, V.; Teusdea, A.C.; Vasile, D.L.; Enescu, R.E.; Crisan, V.E. Biological indicators for evaluating soil quality improvement in a soil degraded by erosion processes. J. Soils Sediments 2019, 19, 2393-2404. [CrossRef]

50. Nannipieri, P.; Ascher, J.; Ceccherini, M.T.; Landi, L.; Pietramellara, G.; Renella, G. Microbial diversity and soil functions. Eur. J. Soil Sci. 2003, 54, 655-670. [CrossRef]

51. Girvan, M.S.; Bullimore, J.; Pretty, J.N.; Osborn, M.; Ball, A.S. Soil type is the primary determinant of the composition of the total and active bacterial communities in arable soils. Appl. Environ. Microbiol. 2003, 69, 1800-1809. [CrossRef] [PubMed]

52. Wolińska, A.; Kuźniar, A.; Zielenkiewicz, U.; Banach, A.; Błaszczyk, M. Indicators of arable soils fatigue-bacterial families and genera: A metagenomic approach. Ecol. Ind. 2018, 93, 490-500. [CrossRef]

53. Sarapatka, B.; Alvarado-Solano, D.P.; Čižmár, D. Can glomalin content be used as an indicator for erosion damage to soil and related changes in organic matter characteristics and nutrients? Catena 2019, 181, 104078. [CrossRef]

54. Seaton, F.M.; George, P.B.L.; Lebron, I.; Jones, D.L.J.; Creer, S.; Robinson, D.A. Soil textural heterogeneity impacts bacterial but not fungal diversity. Soil Biol. Biochem. 2020, 144, 107766. [CrossRef]

55. Lobry de Bruyn, L.; Andrews, S. Are Australian and United States farmers using soil information for soil health management? Sustainability 2016, 8, 304. [CrossRef]

(C) 2020 by the authors. Licensee MDPI, Basel, Switzerland. This article is an open access article distributed under the terms and conditions of the Creative Commons Attribution (CC BY) license (http://creativecommons.org/licenses/by/4.0/). 